This PDF is a selection from a published volume from the National Bureau of Economic Research

Volume Title: High-Skilled Migration to the United States and Its Economic Consequences

Volume Author/Editor: Gordon H. Hanson, William R. Kerr, and Sarah Turner, editors

Volume Publisher: University of Chicago Press

Volume ISBNs: 978-0-226-52552-5 (cloth); 978-0-226-52566-2 (e-ISBN)

Volume URL: http://www.nber.org/books/hans-4

Conference Date: July 10-11, 2016

Publication Date: May 2018

Chapter Title: High-Skilled Immigration and the Comparative Advantage of Foreign-Born Workers across US Occupations

Chapter Author(s): Gordon H. Hanson, Chen Liu

Chapter URL: http://www.nber.org/chapters/c13841

Chapter pages in book: (p. $7-40)$ 


\title{
High-Skilled Immigration and the Comparative Advantage of Foreign-Born Workers across US Occupations
}

\author{
Gordon H. Hanson and Chen Liu
}

\subsection{Introduction}

The increase in the demand for more skilled labor is among the most important changes in the US economy of the last forty years (Katz and Autor 1999). In the narrative crafted by Goldin and Katz (2008), technological advances and rising educational attainment are in something of a race, with the premium for skilled labor rising during periods, as in the 1980s and 1990s, when growth in the supply of college graduates is insufficient to meet the expanding demand for qualified labor. High-skilled immigration changes the nature of the competition between education and technology. Whereas in 1980 the foreign born accounted for only 7.1 percent of prime-age males with a college education, by 2012 this share had reached 17.1 percent. Today, the United States is able to meet the need for a more technologically sophisticated labor force either by growing its own talent through the education and training of native-born workers or by importing talent from abroad (Freeman 2005).

There is growing interest in how and why high-skilled, foreign-born workers enter the US labor market. One important channel of entry is US higher education. Many workers who ultimately obtain US permanent resident visas first enter the country as students (Rosenzweig 2006, 2007). The draw

Gordon H. Hanson holds the Pacific Economic Cooperation Chair in International Economic Relations at the University of California, San Diego, and has faculty positions in the Department of Economics and the School of Global Policy and Strategy, where he also is director of the Center on Global Transformation. He is the acting dean of the school and is a research associate of the National Bureau of Economic Research. Chen Liu is a graduate student in economics at the University of California, San Diego.

For acknowledgments, sources of research support, and disclosure of the authors' material financial relationships, if any, please see http://www.nber.org/chapters/c13841.ack. 
of US universities is due in part to their global standing, especially in science, technology, engineering, and mathematics (STEM). In global rankings of scholarship, US institutions of higher education account for nine of the top ten programs in engineering, for eight of the top ten programs in life and medical sciences, and for seven of the top ten programs in physical sciences. ${ }^{1}$ The lure of studying in the United States also derives from the contact that it facilitates with potential US employers (Bound et al. 2015). A job offer from a US place of business is essential to obtain a temporary work visa or an employer-sponsored green card. Whether foreign students choose to stay in the United States after completing their degrees depends on immediate US and foreign job-market conditions and on prospects for long-run growth in the United States relative to their home countries (Grogger and Hanson 2015).

In this chapter, we consider the possibility that the incorporation of foreign-born workers into the US economy depends on occupational comparative advantage that is at least in part specific to the country in which an individual is born. There is, of course, a long tradition of using comparative advantage to explain international trade in goods, with modern variants of the theory grounding these advantages in cross-country differences in the productivity distributions from which firms draw their industrial capabilities (Eaton and Kortum 2002). There is also a long tradition in labor economics, dating back to Roy (1951), in which workers are posited to vary in their skills for performing different occupational tasks. Recent work combines Eaton and Kortum (2002) with Roy (1951) to obtain models of comparative advantage in which workers are heterogeneous in their capabilities and in which the parameters of the underlying distribution of labor productivity differ between groups of individuals according to their demographic characteristics (Lagakos and Waugh 2013; Hsieh et al. 2013; Burstein, Morales, and Vogel 2015) or their countries of origin (Burstein et al. 2017).

We begin the analysis by documenting the growing presence of foreignborn workers in the US college-educated labor force. This presence varies markedly by occupation. Whereas the share of US college-educated workers who are foreign born rises modestly from 4.2 percent in 1960 to 11.6 percent in 2010-2012 in education, law, and social-service occupations, it rises more impressively from 6.6 percent to 28.1 percent over this same period in STEM occupations. Also notable is the difference in occupational-employment patterns by immigrants according to their country of origin. In STEM jobs, the share of US workers who are from India rises from near zero in 1960 to 9.3 percent, or one-third of all foreign workers, in 2010-2012. In healthrelated occupations, it is workers from Southeast Asia whose employment shares have risen most dramatically, reaching 5.4 percent, or one-fifth of all foreign workers, in 2010-2012 from negligible levels five decades previously.

1. See world university rankings by field at www.arwu.org. 
Specialization patterns are similar for male and female immigrants from the same origin countries.

Next, we use an Eaton-Kortum-Roy definition of comparative advantage to characterize occupational specialization by nationality and over time for college-educated workers. The measure of comparative advantage we use gives the log odds of, say, an Indian immigrant working in STEM over a manual occupation relative to the log odds of a US native-born individual working in STEM over a manual job. We document three features of occupational specialization in the US labor market. First, patterns of specialization by nationality are most extreme in STEM occupations. Among primeage male college graduates, an immigrant from India is 10.7 times more likely than a US native-born individual to work in STEM over a manual job and 54.6 times more likely to do so than an immigrant from Mexico, Central America, and the Caribbean. Second, occupational specialization for male and female immigrant college graduates is strongly positively correlated across origin countries, with a partial correlation of male-female comparative advantage in 2010-2012 of 0.92 in STEM jobs, 0.86 in management and finance, and 0.71 in health-related occupations. Third, immigrant occupational specialization patterns persist firmly over time. For college-educated men, a regression of log comparative advantage in 2010 against the value in 1990 across birth countries yields very precisely estimated slope coefficients of 0.99 in STEM occupations, 1.02 in management and finance, and 1.01 in education, law, and social-service occupations. We take these results to mean that the factors that drive occupational specialization among immigrants are stable across decades and common to workers in different demographic groups from the same origin countries.

High-skilled immigration has important consequences for US economic development. In modern growth theory, the share of workers specialized in R\&D plays a role in setting the pace of long-run growth (Jones 2002). Because high-skilled immigrants are drawn to STEM fields, they are likely to be inputs into US innovation. Recent work finds evidence consistent with high-skilled immigration having contributed to advances in US innovation. US states and localities that attract more high-skilled foreign labor see faster rates of growth in labor productivity (Hunt and Gauthier-Loiselle 2010; Peri 2012). Kerr and Lincoln (2010) find that individuals with ethnic Chinese and Indian names, a large fraction of whom appear to be foreign born, account for rising shares of US patents in computers, electronics, medical devices, and pharmaceuticals. US metropolitan areas that historically employed more H-1B workers enjoyed larger bumps in patenting when Congress temporarily expanded the program between 1999 and 2003. Further, the patent bump was concentrated among Chinese and Indian inventors, consistent with the added $\mathrm{H}-1 \mathrm{~B}$ visas having expanded the US innovation frontier. Yet, the precise magnitude of the foreign-born contribution to US innovation and productivity growth is hard to pin down. Because the alloca- 
tion of labor across regional markets responds to myriad economic shocks, establishing a causal relationship between inflows of foreign workers and the local pace of innovation is a challenge. High-skilled immigration may displace some US workers in STEM jobs (Borjas and Doran 2012), possibly attenuating the net impact on US innovation capabilities. How much of aggregate US productivity growth can be attributed to high-skilled labor inflows remains unknown.

When it comes to innovation, there appears to be nothing "special" about foreign-born workers, other than their proclivity for studying STEM disciplines in a university. The National Survey of College Graduates shows that foreign-born individuals are far more likely than the native born to obtain a patent, and more likely still to obtain a patent that is commercialized (Hunt 2011). It is also the case that foreign-born students are substantially more likely to major in engineering, math, and the physical sciences, all fields strongly associated with later patenting. Once one controls for the major field of study, the foreign-native-born differential in patenting disappears. Consistent with Hunt's (2011) findings, the descriptive results we present suggest that highly educated immigrant workers in the United States have a strong revealed comparative advantage in STEM. The literature has yet to explain the origin of these specialization patterns. It could be that the immigrants the United States attracts are better suited for careers in innovation - due to the relative quality of foreign secondary education in STEM, selection mechanisms implicit in US immigration policy, or the relative magnitude of the US earnings premium for successful inventors - and therefore choose to study the subjects that prepare them for later innovative activities. Alternatively, cultural or language barriers may complicate the path of the foreign born to obtaining good US jobs in non-STEM fields, such as advertising, insurance, or law, pushing them into STEM careers.

To understand possible sources of occupational comparative advantage by immigrants from different origin countries, we compare our measures of occupational specialization across three groups of individuals according to their nativity. Immigrants born and raised in an origin country (who arrived in the United States at age eighteen or older) would have been exposed to foreign educational institutions, at least through secondary school. Immigrants born in the origin country but raised in the United States (who arrived in the United States before age eighteen) would have been exposed to US education, at least at the university level. And individuals whose parents or grandparents were born in the origin country would have been exposed to US education throughout their lives. Occupational specialization patterns are similar across these three groups, suggesting that the country in which one is educated is not the overriding factor that explains employment regularities among highly educated immigrants.

In section 1.2, we present the data used in the analysis. In section 1.3, 
we describe the presence of foreign-born, college-educated workers in US occupations. In section 1.4, we define and measure occupational comparative advantage among US immigrants according to their country of origin. And in section 1.5, we provide a concluding discussion.

\subsection{Data}

We use data from the Census Integrated Public Use Micro Samples (Ruggles et al. 2010) for the years 1960 (5 percent sample), 1970 (1 percent sample), 1980 (5 percent sample), 1990 (5 percent sample), and 2000 (5 percent sample), and the American Community Survey (ACS) for 2010 to 2012. We pool ACS files for 2010 through 2012 to increase sample size and, hence, measurement precision.

Throughout our analysis, we restrict the sample to individuals with positive earnings, who are between twenty-one and fifty-four years old at the time of the survey, and who have at least a bachelor's degree. Our focus on college graduates follows from our interest in the high-skilled labor force. The age restrictions we impose allow us to center on prime-wage workers who are likely to have completed their undergraduate studies. To measure employment, we calculate the number of full-time equivalent workers in given national origin, gender, and occupation categories by using weights equal to the sampling weight for an individual times her hours of work last year, which we take to be the product of weeks worked last year and usual hours worked per week. The US native-born population comprises individuals who were born either in the United States or abroad to parents who are US citizens. The foreign-born population comprises all other individuals.

To accommodate a perspective that spans six decades and dozens of source countries for immigrants, we aggregate occupations into six broad categories. Aggregation helps avoid having large numbers of cells with zero entries, which is of particular concern for smaller source countries and in earlier years. The occupation categories are

- STEM (architects, computer programmers and software developers, engineers, life and medical scientists, and physical scientists);

- management, finance, and accounting (accountants, chief executives, financial managers, general managers, market surveyors, and economists);

- health (dentists, pharmacists, physicians, registered nurses, therapists, and veterinarians);

- education, law, social work, and the arts (instructors and teachers, lawyers, social and religious workers, writers, and artists);

- technical, sales, and administrative support (administrative support staff, clerks and record keepers, sales representatives, sales supervisors, and technicians); and 
- less-skilled manual work (agricultural workers, construction workers, hospitality workers, household-service workers, machine operators and production workers, mechanics and repairers, and personal-service workers).

These categories divide occupations according to the level of education, the type of training, and the range of skills that are demanded on the job. Most STEM occupations require at least a bachelor's degree, as well as aptitude in quantitative reasoning. Because quantitative skills are grounded in mathematical logic, they may transfer from one country to another with relative ease, making human capital acquired in STEM jobs relatively portable across borders. Although management positions also require some familiarity with quantitative reasoning, they are intensive in the use of communication and other social skills to a degree that STEM positions are not. Health, education, law, and social work are distinguished by requiring a bachelor's degree or higher to enter these professions and by being subject to occupational accreditation processes that are specific to the United States or to individual states within the country. Accreditation may limit the portability of skills for immigrants in these professions. The final two occupational categories - manual work and technical, sales, and administrative support - typically do not require a college degree. The first category includes jobs from which advancement to higher-level positions is usually limited. The second encompasses jobs through which more-educated immigrants may first enter the labor force as they seek to establish their position in a new labor market.

\subsection{Foreign-Born Presence in US Occupations}

We begin the analysis by describing the presence of immigrants in US occupations, first for college-educated males and then for college-educated females. We then consider the specialization of immigrants from different origin countries in particular types of jobs. For ease of presentation, we present trends for immigrants grouped according to six sending regions: China, Hong Kong, and Taiwan; Eastern and Western Europe; East and Southeast Asia; India; Mexico, Central America, and the Caribbean; and South America. China and India merit attention because they account for a disproportionate share of the recent growth in US high-skilled immigration. ${ }^{2}$ Europe, a historic but now less important source of US high-skilled immigrants, offers an instructive contrast. East and Southeast Asia include Korea, long a source of high-skilled immigrants to the United States, and the Philippines and Vietnam, which supply immigrants at both low- and high-education levels. The two regions from Latin America and the Carib-

2. Since 1990, nearly all of the growth in US immigration from China, Hong Kong, and Taiwan is due to immigration from mainland China. 
bean are the predominant sources of low-skilled immigrants to the United States, making them of interest in terms of their less studied, high-skilled labor outflows. Although we leave Africa and the Middle East out of the figures in this section, we will include these regions in the analysis presented in the following section.

\subsubsection{College-Educated Males}

Figure 1.1 shows the share of the foreign born in total US male employment of college graduates, as measured by hours worked, for six immigrant source regions in each of the six occupational groups. It displays the wellknown pattern of a growing presence of highly educated immigrants in the US labor force. Across all origin countries, the foreign-born share of total hours worked by prime-age male college graduates increases from 6.6 percent in 1960 to 28.1 percent in 2010-2012 in STEM occupations; from 4.1 percent to 14.9 percent in management and finance; from 10.7 percent to 24.7 percent in health-related occupations; from 4.2 percent to 11.6 percent in education, law, and social work; from 3.8 percent to 13.1 percent in technical, sales, and administrative support; and from 7.8 percent to 18.8 percent in manual occupations.

In 1960, Europe was by far and away the major origin region for highskilled immigrants to the United States. Whereas Europe's share of occu-
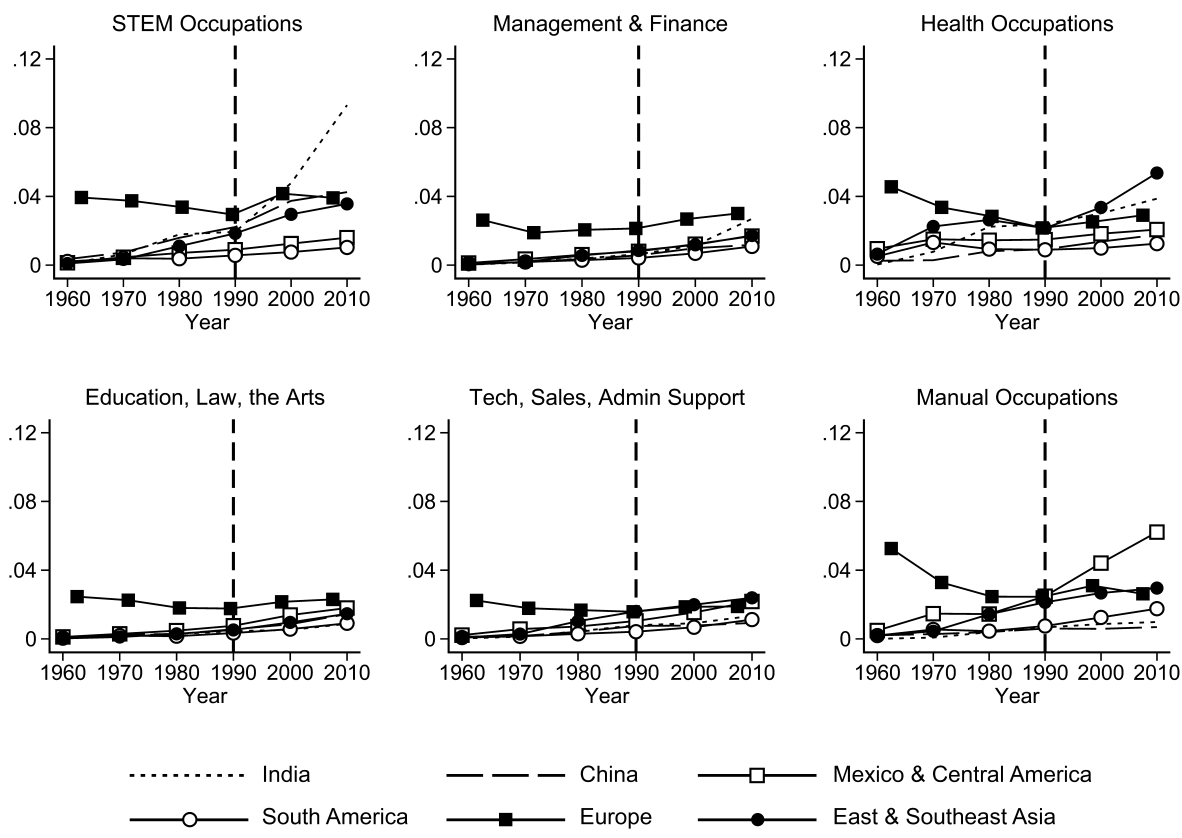

Mexico \& Central America East \& Southeast Asia

Fig. 1.1 Share of immigrants in US occupational employment, males 
pational employment in 1960 ranged between 2 and 6 percent, no other region even topped 1 percent. Europe's importance reflects historical US immigration policies, which between 1924 and 1965 allocated visas based on national quotas that favored European countries (Ngai 1999; Udansky and Espenshade 2000).

In the decades since 1960, Europe's role as the primary source for newly arrived high-skilled US immigrants has been supplanted by Asia. By the period 2010 to 2012, immigrants from India, at 9.3 percent of collegeeducated US employment, were the largest foreign-born group in US STEM occupations, and immigrants from East and Southeast Asia, at 5.4 percent of employment, were the largest foreign-born group in US health-related occupations. Among the six occupational categories in figure 1.1, Europe remained the top immigrant-supply region in 2010-2012 in just two, management and finance, where it held a slim lead over India at 3.1 percent versus 2.7 percent of US employment of the college educated, and education, law, social work, and the arts, where it held another slim lead in this case over Mexico and Central America at 2.3 percent versus 1.8 percent of US employment.

Asia's rise as a source of high-skilled immigrants is the result of multiple factors. The Immigration and Nationality Act of 1965 replaced nationalorigin quotas with a quota-allocation scheme that favored family members of US residents, and, to a lesser degree, skilled workers demanded by US employers. Over time, this change in policy allowed non-European countries to join the queue for US immigration visas. One common route through which foreign-born individuals gain a permanent residence or temporary work visa is by first completing undergraduate or graduate study in the United States (Kato and Sparber 2013; Salzman, Kuehn, and Lowell 2013). Being a student at a US university facilitates contact with US employers (Bound et al. 2015) and creates opportunities to meet and to marry a US resident (Jasso et al. 2000), either of which earns one a place in the queue for a green card. Due in part to its rapidly expanding supply of college students, Asia has become a leading source of foreign students in US universities. As of the 2013/14 academic year, six of the top ten source countries for foreign students in the United States were from Asia (Institute of International Education 2015). ${ }^{3}$ These countries accounted for 57.4 percent of the 886,052 foreign students studying at US institutions. ${ }^{4}$ The four highest-ranking European countries on the list accounted for just 3.6 percent of US foreign

3. These countries in descending rank order are China, India, Korea, Taiwan, Japan, and Vietnam.

4. This total includes undergraduate students, graduate students, nondegree students, and students in Optional Practical Training. Together, undergraduate and graduate students accounted for an average of 88.3 percent of foreign students in the United States in the 1990s and first decade of the twenty-first century. 
students in that year. ${ }^{5}$ Within Asia, China and India stand out as leading origin countries for foreign students. Their shares of the US foreign-student population grew from 8.7 percent and 6.9 percent, respectively, in 1989-1990 to 31.2 percent and 13.6 percent, respectively, in 2013-2014.

In addition to geographic diversification in source regions for US highskilled immigration, two other patterns in figure 1.1 call one's attention. One is that 1990 is an inflection point for immigrant presence in US employment. It is after 1990 when India's and China's presence in STEM occupations rises most dramatically and when Southeast Asia's and India's presence in health-related occupations begins to take off. One contributing factor to this growth is the $\mathrm{H}-1 \mathrm{~B}$ program for temporary high-skilled, foreign-born workers, which Congress created as part of the Immigration Act of $1990 .{ }^{6}$ The US government first allocated $65,000 \mathrm{H}-1 \mathrm{~B}$ visas per year, which it raised to 115,000 per year in 1999 and to 195,000 in 2001, before settling at 85,000 per year in 2006 (General Accounting Office 2011). ${ }^{7}$ Since these visas are for a period of three years and are renewable once, a single visa expands the supply of high-skilled US immigrants by up to six person years. If all visa recipients stay for a full three-year term, in steady state a supply of 85,000 temporary visas would accommodate a rotating stock of 255,000 immigrants. If these recipients in turn each renew their visas and stay for a full additional three-year term, the initial visa allocation would accommodate a rotating stock of 510,000 visa holders.

Of course, far from all H-1B visa recipients extend their visas or even stay for their complete initial three-year terms. ${ }^{8}$ Nevertheless, given that the total stock of US immigrants in 2010-2012 age twenty-one to fifty-four years old with a college education was 5.8 million, a temporary visa program of the magnitude of the $\mathrm{H}-1 \mathrm{~B}$ is capable of bringing about a sizable increase in immigrant labor supply. In practice, the H-1B visa appears to operate as a queue for a green card (Lowell 2000). Congress allocates 140,000 employersponsored green cards each year. It is common for employers to first seek

5. These countries in descending rank order are the United Kingdom, Germany, France, and Spain.

6. The H-1B program is the largest and most well known source of temporary work visas for high-skilled US workers, but it is far from the only such program. Other programs that supply high-skilled immigrants with temporary work visas include the L-1 visa (for intracompany transferees, which allows foreign workers of US multinational companies to work in the United States), the $\mathrm{O}$ visa (for individuals of extraordinary ability or achievement), the $\mathrm{P}$ visa (for artists, athletes, and entertainers), and the TN visa (for professional workers from NAFTA countries). To give a sense of the relative scale of these programs, in 2008 the United States issued $129,000 \mathrm{H}-1 \mathrm{~B}$ visas (the sum of new visas and visa extensions) and 84,000 L-1 visas.

7. The current level of $85,000 \mathrm{H}$-1B visas includes 65,000 visas for temporary immigrant workers in specialty occupations and 20,000 visas for foreign-born individuals who have earned an advanced degree from a US institution of higher education.

8. Clemens (2010) finds that for an Indian software company in the middle of the first decade of the twenty-first century, just 44.8 percent of H-1B visa recipients were in the United States two years after obtaining a visa. 


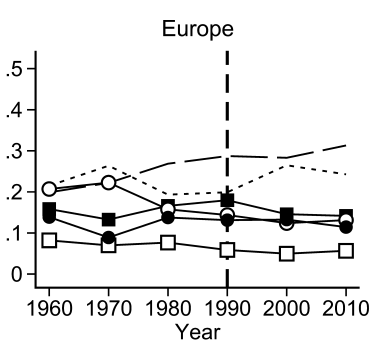

East \& Southeast Asia

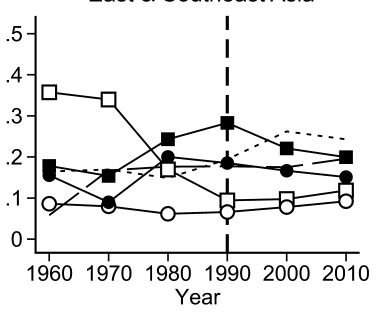

STEM Occupations

Education, Law, the Arts
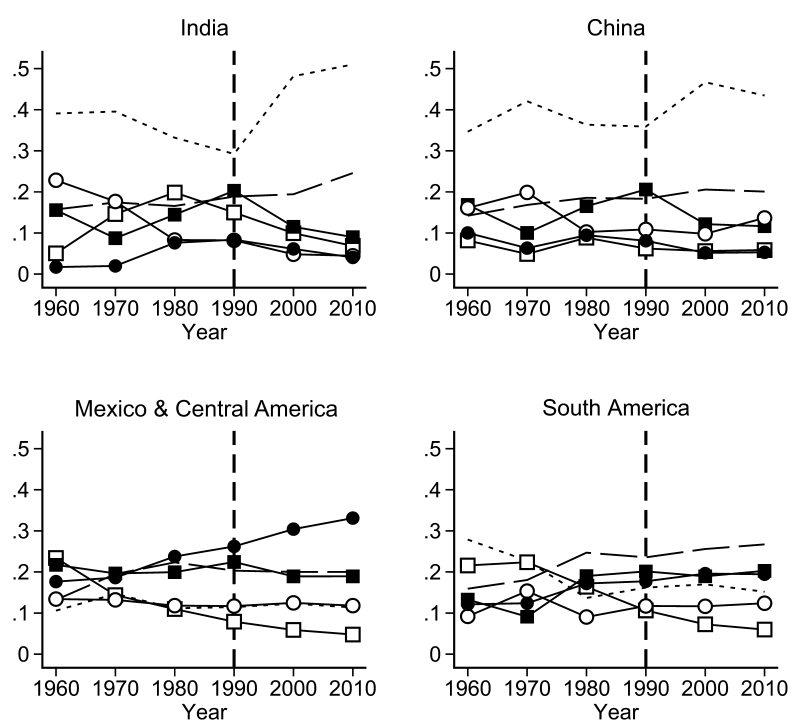

$-\longrightarrow$ Management \& Finance
$\longrightarrow-$ Tech, Sales, Admin Support

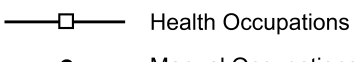

Fig. 1.2 Share of occupation in immigrant employment by national origin, males

H-1B visas for foreign employees, and later, depending on their performance and desire to stay in the United States, to apply for a green card on their behalf. The two largest recipient countries for H-1B visas are India and China. Over the 2000-2009 period, they accounted for 46.9 percent and 8.9 percent, respectively, of approved H-1B workers (General Accounting Office 2011).

A second pattern evident in figure 1.1 is variation in occupational specialization patterns by immigrants from different origin regions. To see these details more clearly, in figure 1.2 we plot the share of total labor hours worked by male college graduates from each of the six immigrant origin regions in each of the six occupational categories. India's and China's specialization in STEM is strongly apparent in figure 1.2, with occupations in this group in 2010-2012 accounting for 51.0 percent of Indian immigrant employment and 43.5 percent of Chinese immigrant employment. Although STEM occupations are also the top employment category for immigrants from East and Southeast Asia, the sector's dominance is much less pronounced for this region than for India and China. For immigrants from Europe and South America, management and finance is the top occupation for male college graduates, whereas for immigrants from Mexico and Central America, the top category is health-related professions. These patterns are a first indication of differences in occupational comparative advantage 
for immigrants from difference source countries. In the following section, we examine occupational specialization by immigrants in more detail.

\subsubsection{College-Educated Females}

We next examine high-skilled immigration among women and occupational specialization by female immigrants according to their region of birth. Analogous to figure 1.1 for males, figure 1.3 shows the share of the foreign born in total US female employment of college graduates for six immigrant source regions in each of the six occupational groups. Similar to patterns for men, immigrant presence in high-skilled female employment has increased substantially over time. Across all origin countries, the foreign-born share of total hours worked by prime-age female college graduates increases from 9.2 percent in 1960 to 31.1 percent in 2010-2012 in STEM occupations; from 4.6 percent to 14.5 percent in management and finance; from 8.5 percent to 17.9 percent in health-related occupations; from 2.3 percent to 8.7 percent in education, law, social work, and the arts; from 6.8 percent to 13.9 percent in technical, sales, and administrative support; and from 17.3 percent to 21.4 percent in manual occupations.

As with men, in 1960 Europe begins as the dominant source region for college-educated immigrant women and by the first decade of the twentyfirst century is replaced by another region in all six occupational categories.
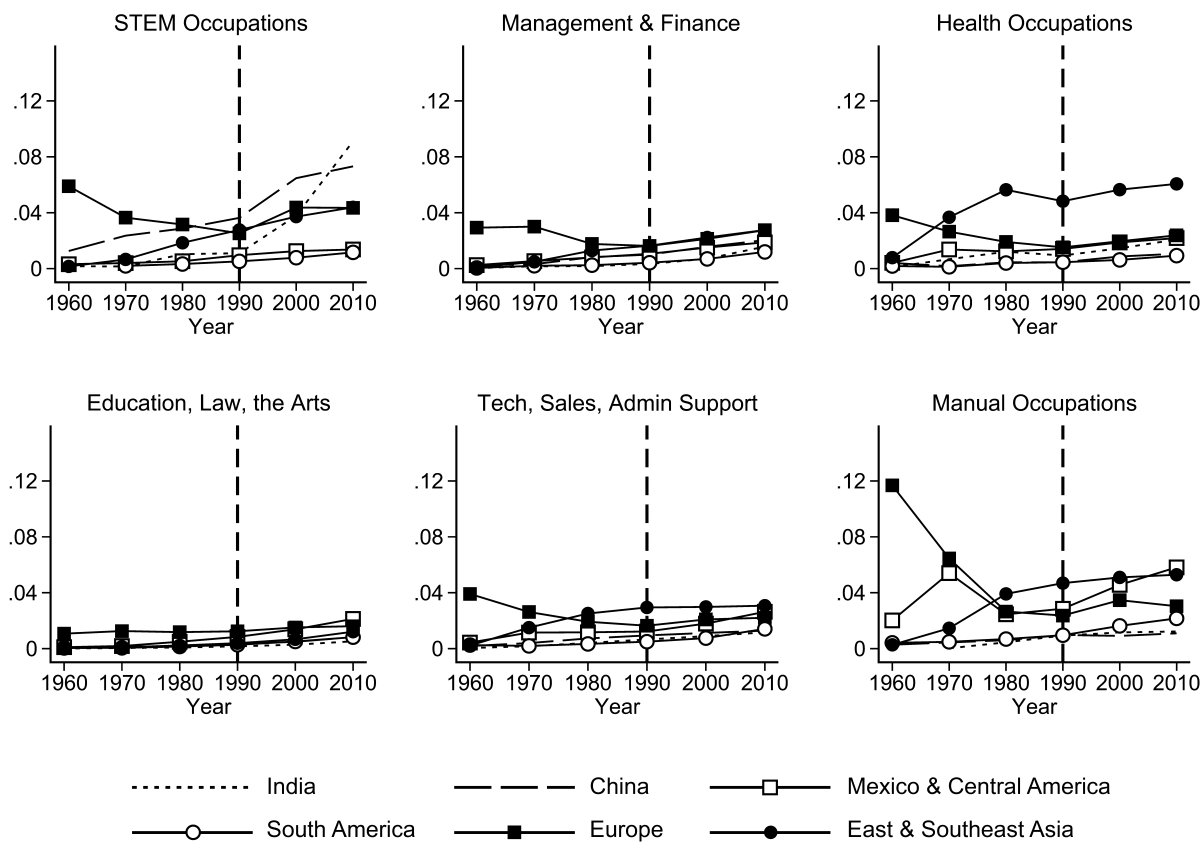

Fig. 1.3 Share of immigrants in US occupational employment, females 
India and China become the largest immigrant-origin regions in STEM occupations; Southeast Asia becomes the largest immigrant-origin region in health-related occupations; and Mexico and Central America become the largest immigrant-origin regions in manual occupations. In 2010-2012, female immigrants from India and China represent 9.1 percent and 7.3 percent of US female STEM employment, compared to 9.3 percent and 4.2 percent for these regions, respectively, among men. Immigrant women from East and Southeast Asia account for 6.1 percent of female employment in health-related occupations, compared to 5.4 percent for this region among men. And immigrant women from Mexico and Central America account for 5.8 percent of female employment in manual occupations, compared to 6.2 percent for this region among men. These findings are broadly suggestive that occupational specialization patterns are more country-of-origin specific than gender specific.

To explore occupational specialization in more detail, figure 1.4, similar to figure 1.2, plots the share of total labor hours worked by female college graduates from each of the six immigrant origin regions in each of the six occupational categories. Although occupational specialization among female immigrants is less extreme than among men, male and female immigrants from some origin regions tend to specialize in similar lines of work. For immigrants from Europe, the top category for both men and women is
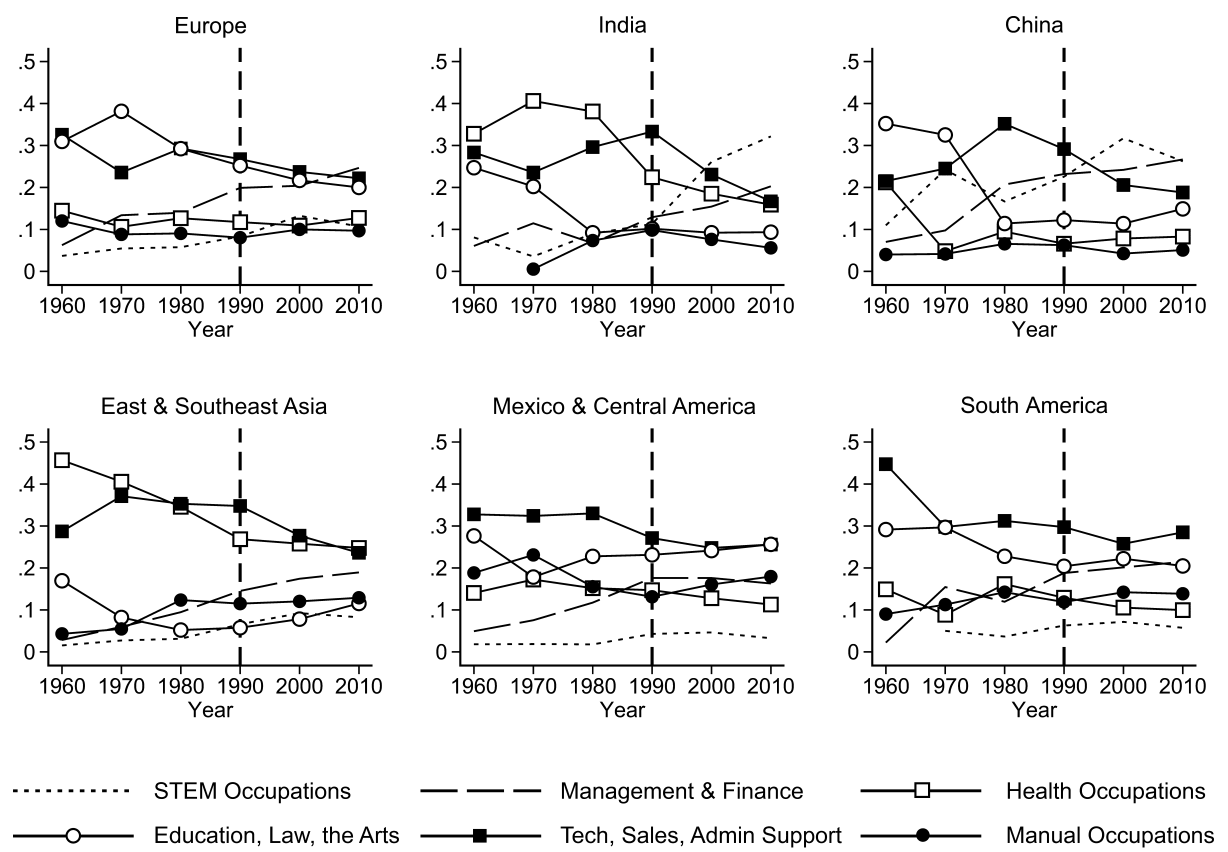

Fig. 1.4 Share of occupation in immigrant employment by national origin, females 
management and finance, and for immigrants from India and China, it is STEM occupations. For Southeast Asia and Latin America, however, the less skill-intensive activities of technical, sales, and administrative support and manual occupations are the largest categories of female employment, distinct for patterns for men from these regions.

Entering the United States on a student visa and later transitioning to a green card appears to be a common path for settlement in the United States among high-skilled immigrant women, as it is for high-skilled immigrant men. Yet, the large majority of H-1B visas appear to go to men, suggesting that the student-visa-to-H-1B-to-green-card transition path is primarily open to male workers (and in particular those in the technology sector). The literature contains little information about differences by gender in how immigrants enter and remain in the United States.

\subsection{Comparative Advantage of Foreign-Born Workers}

The previous section reveals that immigrant presence in the US highskilled labor force has grown over time, that immigrant presence has risen much more strongly in some occupations (STEM, management, and finance) than in others (education, law, social work, and the arts), and that the propensity to specialize in particular occupations varies by region of birth. In this section, we define, measure, and evaluate comparative advantage across broad occupations for high-skilled immigrants, where we allow advantage to vary both over time and by origin country.

\subsubsection{Defining Comparative Advantage}

We consider the possibility that specialization patterns arise from occupation-specific differences in worker productivity across source countries. As a result of cross-country variation in the quality of higher education, traditions of excellence in particular academic disciplines, or other institutions through which individuals acquire occupation-specific skills, workers from particular countries may be relatively likely to develop aptitudes that are highly valued in particular occupations. Russia's long tradition of excellence in mathematics, for instance, may result in college graduates from Russia being relatively likely to pursue careers in engineering, mathematics, or physics.

Consider a Roy model of occupational sorting, as in Lagakos and Waugh (2013), Hsieh et al. (2013), or Burstein, Morales, and Vogel (2015). Suppose that college-educated workers from origin-country and gender groups, indexed by $\lambda$, choose the country in which to reside, indexed by $\kappa$, and an occupation in which to work, indexed by $\sigma$. Suppose also that productivity for an individual from origin country $\lambda$ (e.g., India) working in occupation $\sigma$ (e.g., software programming) in destination $\kappa$ (e.g., the United States) is determined by a random draw from a Fréchet distribution, with location 
parameter $T_{\lambda, \kappa, \sigma}$. We allow productivity to be $\lambda-\kappa$ specific, as may result from variation across origin countries $\lambda$ in the portability of human capital to destination country $\kappa, \lambda-\sigma$ specific, as may result from variation across origin countries $\lambda$ in the aptitude for occupation $\sigma$ (e.g., the excellence of Russian mathematicians), and $\kappa-\sigma$ specific, as may result from variation across destination countries $\kappa$ in the productivity of workers in occupation $\sigma$ (e.g., the success of the United States in software services). We can then derive a simple expression for comparative advantage in which the productivity for a worker from origin country $\lambda$ in occupation $\sigma$ relative to some base occupation $\sigma^{\prime}$ (e.g., software programming versus manual work) is compared to relative productivity in the same two occupations for a worker from a base country ( $\lambda_{\text {us }}=$ United States), where these productivities are evaluated in a common destination market ( $\kappa_{\text {us }}=$ United States). This expression is given by,

$$
\frac{T_{\lambda, \kappa_{u s}, \sigma}}{T_{\lambda, \kappa_{\mathrm{us}}, \sigma^{\prime}}} / \frac{T_{\lambda_{\mathrm{us}}, \kappa_{\mathrm{us}} \sigma}}{T_{\lambda_{\mathrm{us}}, \kappa_{\mathrm{us}}, \sigma^{\prime}}}=\frac{\Phi_{\lambda, \mathrm{\kappa}_{\mathrm{us}}, \sigma}}{\Phi_{\lambda, \kappa_{\mathrm{us}}, \sigma^{\prime}}} / \frac{\Phi_{\lambda_{\mathrm{us}}, \kappa_{\mathrm{us}}, \sigma}}{\Phi_{\lambda_{\mathrm{us}}, \kappa_{\mathrm{us}}, \sigma^{\prime}}} .
$$

where $\Phi_{\lambda, \kappa_{\text {us }, \sigma}}$ denotes the share of workers from origin-country gender group $\lambda$ (India, males) working in the United States $\left(\kappa_{\mathrm{us}}\right)$ in occupation $\sigma$ (software programming). Equation (1) states that the employment shares of Indian immigrants relative to US native-born workers in software programming relative to manual jobs reveals the comparative advantage of Indian immigrants in programming. By comparing employment shares for workers from a common origin-country gender group (India, males) in two distinct occupations (software programming vs. manual work) in the United States, we neutralize the average productivity loss incurred by immigrants from India when working in the United States. Similarly, by comparing employment shares for workers from two distinct origin countries (India vs. the United States) in the same occupation, we neutralize productivity effects specific to the occupation in the destination market.

We evaluate the revealed comparative advantage of immigrants from different origin countries working in the United States using the log of the expression on the right of equation (1). Throughout the analysis, we treat US-born workers as the base demographic group and manual work support as the base occupational category. Although equation (1) suppresses time subscripts, we will allow comparative advantage to evolve freely over time. Because of the double differencing in equation (1), the evolution of comparative advantage will be free of the effects of changes in the average productivity of Indian immigrants or in average labor productivity in US software programming.

\subsubsection{Comparative Advantage of Foreign-Born Relative to Native-Born Workers}

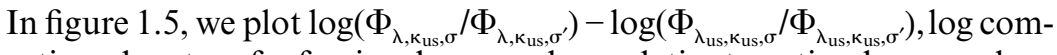
parative advantage for foreign-born workers relative to native-born workers 

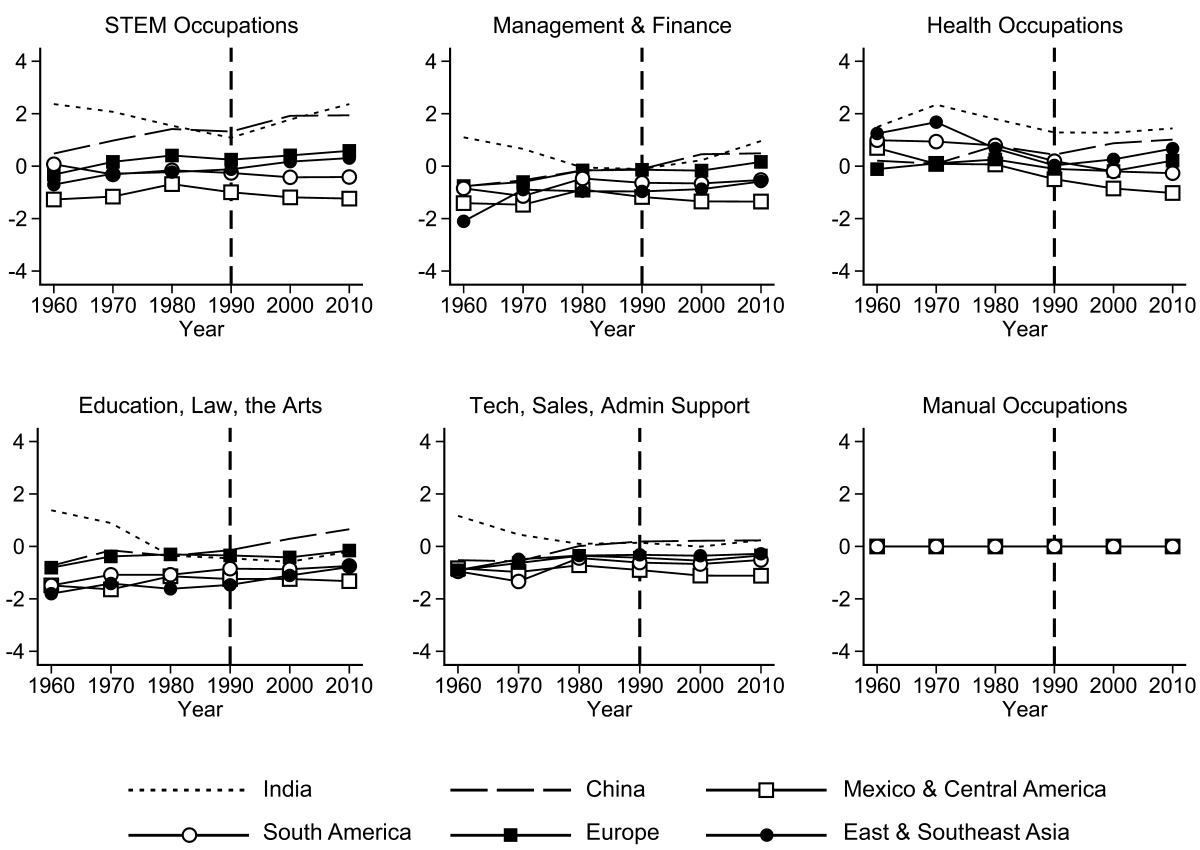

Fig. 1.5 Log comparative advantage by occupation, males relative to US counterparts

in an occupation using manual jobs as the base category, for each nonbase occupation in the six origin regions over time, where the sample is male prime-working-age college graduates. Given the double log difference form, a positive value of log comparative advantage for an origin group in an occupation indicates comparative advantage relative to US workers and a negative value indicates comparative disadvantage relative to US workers.

It is in STEM occupations that variation in comparative advantage across origin regions is most pronounced. Male college-educated immigrants from India and China exhibit a strong revealed comparative advantage in STEM jobs, whereas immigrants from Europe and Southeast Asia display a modest advantage in the sector, and immigrants from Latin America possess a clear disadvantage in STEM. The direct implication is that US college-educated men have a disadvantage in STEM relative to manual occupations when compared to immigrants from India and China and an advantage when compared to immigrants from Latin America. In 2010-2012, figure 1.5 shows that the log difference in the likelihood of Indian immigrants working in STEM over manual occupations when compared to US native-born men is 2.37 , for European immigrants it is 0.59 , for Southeast Asian immigrants it is 0.31 , for immigrants from South America it is -0.41 , and for Mexican and Central American immigrants it is -1.23 . This quantity is the relative log odds of working in an occupation for immigrants from a particular origin 
region. It is worth pausing for a moment to appreciate the magnitude of the differences in occupational specialization patterns that these log odds imply. Male immigrants from India are 10.7 times $(\exp \{2.37\})$ more likely to work in STEM than in manual jobs, when compared to US native-born men, and 7.9 times $(\exp \{2.37-0.31\})$ more likely to do so, when compared to male immigrants from Southeast Asia.

In other occupations, comparative advantage of immigrant men relative to US native-born men is compressed when evaluated against STEM. Relative to US native-born men, the log odds of working in management and finance (over manual jobs) range from 0.96 for Indian immigrants to -1.35 for Mexican and Central American immigrants, the relative log odds of working in health-related occupations range from 1.43 for Indian immigrants to -1.02 for immigrants from Mexico and Central America, the relative log odds of working in education and law range from 0.65 for Chinese immigrants to -1.33 for Mexican and Central American immigrants, and the relative log odds of working in technical, sales, and administrative support range from 0.23 for Chinese immigrants to -1.12 for immigrants from Mexico and Central America. The pervasive negative log odds for immigrants from Mexico and Central America reveal that in the US economy, their revealed comparative advantage (when compared to college graduates from other origin regions) lies in manual occupations.

In figure 1.6, we show the analogous log comparative advantage plots for women. The patterns are broadly similar to those for men. In STEM, college-educated immigrants from India and China display a strong comparative advantage, whereas immigrants from Mexico and Central America display a comparative disadvantage. STEM is again the sector with the widest variation in comparative advantage. In 2010-2012, the log difference in the likelihood of Indian immigrant women working in STEM over a manual job when compared to US native-born women is 2.13 and for Mexican and Central American immigrants it is -1.31 . Relative to US native-born women, the log odds of working in management and finance (over manual jobs) range from 0.54 for Chinese immigrants to -1.21 for Mexican and Central American immigrants, the relative log odds of working in healthrelated occupations range from 0.48 for Indian immigrants to -1.02 for immigrants from Mexico and Central America, the relative log odds of working in education and law range from -0.44 for Chinese immigrants to -1.62 for Southeast Asian immigrants, and the relative log odds of working in technical, sales, and administrative support range from 0.07 for Chinese immigrants to -0.88 for immigrants from Mexico and Central America.

What explains differences in occupational specialization across US workers according to their country of birth? One possibility is that the quality or availability of education in science varies across countries (Hanushek and Kimko 2000), with differences in math and science perhaps being most important. To obtain a job in STEM generally requires a college or advanced 

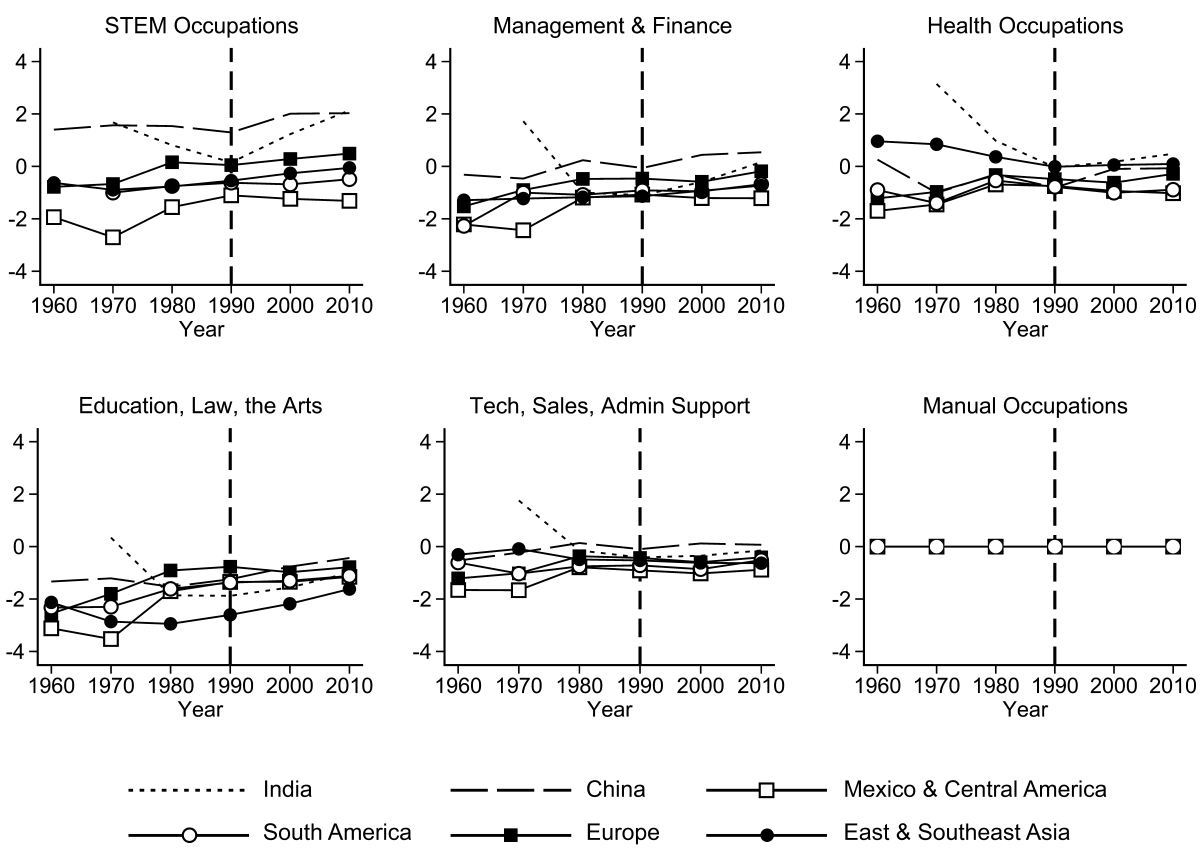

Fig. 1.6 Log comparative advantage by occupation, females relative to US counterparts

degree in a STEM discipline. US students and students from Latin America may begin their undergraduate studies with relatively poor math and science skills, which leaves them ill equipped to complete an engineering or science degree. When it comes to STEM disciplines, US secondary-school students do tend to underperform their peers from other high-income nations. In the 2012 PISA exam, US fifteen-year-olds ranked 36th in math and 28th in science out of sixty-five participating countries. ${ }^{9}$ Students from Latin America also underperform on PISA exams relative to countries at similar income levels. Among the eight Latin American countries that participated in the 2012 exam, the highest-ranking country was Chile at 51st in math and 46th in science.

A second possible explanation for immigrant success in obtaining STEM jobs is that these are jobs in which workers educated or trained abroad can signal their skills to employers at relatively low cost. In some non-STEM professional fields, such as insurance and marketing, the foreign born may have an absolute disadvantage because they lack a nuanced understanding of American culture or because subtleties in face-to-face communication are an important feature of interactions in the marketplace. Others of these

9. See www.oecd.org/pisa. 
fields, such as the law or real estate, may involve an occupational accreditation process that imposes relatively high entry costs on those educated or trained abroad. A related explanation is that there are network effects in job search, which result in a tendency for immigrants from particular origin countries to cluster in specific occupations (Card 2001).

A third possible explanation is that US immigration policy has implicit screens that favor more-educated immigrants in STEM fields over those in non-STEM fields. Although H-1B visas do go in disproportionate numbers to workers in STEM occupations (Kerr and Lincoln 2010), there is nothing preordained about this outcome in terms of US immigration policy. H-1B visas are designated for "specialty occupations," which are not limited to jobs in the technology sector. ${ }^{10}$ That most H-1B visas are captured by STEM workers may simply be the consequences of strong relative demand for foreign STEM labor by US companies.

\subsubsection{Persistence in Comparative Advantage}

In figures 1.5 and 1.6, there is only modest variation in occupational comparative advantage over time, especially in the second half of the sample period from 1990 forward. This suggests that occupational comparative advantage for college-educated immigrants is persistent at the level of sending countries. To characterize the degree of this persistence, in figure $1.7 \mathrm{we}$ plot log immigrant comparative advantage in STEM occupations (relative to manual occupations) in 2010 versus 1990. The 45-degree schedule is shown as a solid line and the regression plot as a dashed line. We expand the sample to include all origin regions for US immigrants. We present data for the thirty largest sending countries for immigrants and for remaining countries aggregated into ten regional groups. ${ }^{11}$ To make within-country comparisons as precise as possible, we control for differences in the age composition of immigrants by restricting the sample to be individuals twenty-one to thirtyseven years old (as compared to the full sample of individuals twenty-one to fifty-four years old used in previous sections).

In figure 1.7, panel A, which displays results for college-educated males,

10. Specialty occupations are ones in which (a) a bachelor's or higher degree or its equivalent is normally the minimum entry requirement for the position, (b) the degree requirement is common to the industry in parallel positions among similar organizations, (c) the employer normally requires a degree or its equivalent for the position, or (d) the nature of the specific duties is so specialized and complex that the knowledge required to perform the duties is usually associated with attainment of a bachelor's or higher degree. See http://www.uscis.gov/eir/visa -guide/h-1b-specialty-occupation/understanding-h-1b-requirements.

11. The twenty-nine largest sending countries for college-educated immigrants are Bangladesh, Brazil, Canada, China, Colombia, Cuba, the Dominican Republic, Egypt, France, Germany, Great Britain, Haiti, Hong Kong, India, Iran, Japan, Jamaica, Korea, Mexico, Nigeria, Peru, the Philippines, Pakistan, Poland, Russia, Spain, Taiwan, Venezuela, and Vietnam. The ten regional groups are Central America, South America, Western Europe, Southern Europe, Eastern Europe, South Asia, Southeast Asia, Middle East and North Africa, sub-Saharan Africa, and Oceania. 
A. Males, STEM Occupations

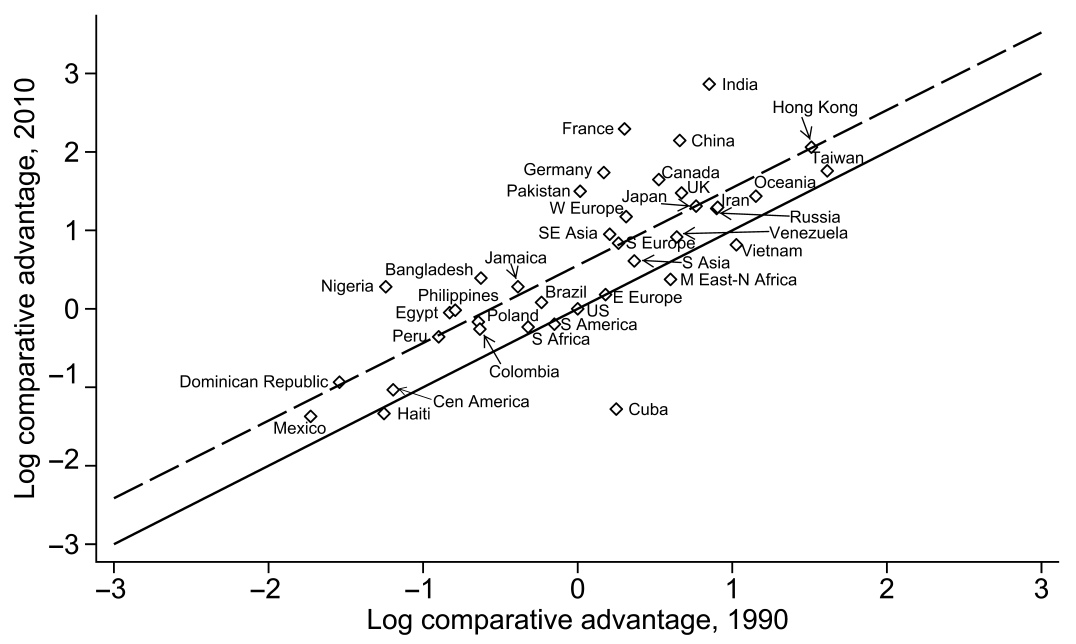

$\diamond \log C A-45$ degree line $-\longrightarrow$ Regression fit

B. Females, STEM Occupations

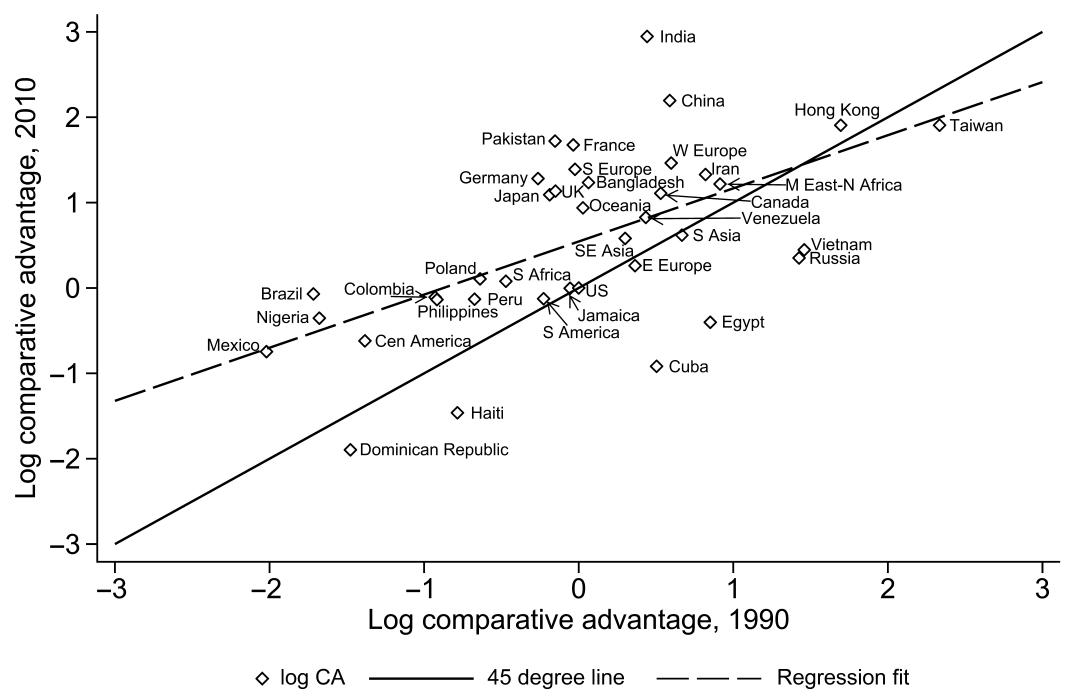

Fig. 1.7 Log comparative advantage for immigrants in STEM, 2010 versus 1990

we see evidence of strong persistence over time in comparative advantage in STEM occupations for immigrants by country of origin. The regression of log comparative advantage in STEM for 2010 against the 1990 value yields a slope coefficient estimate of 0.99 ( $t$-value 7.5) and an $R^{2}$ of 0.60 $(N=40)$. Further evidence reveals that this persistence is not a new phenomenon in the US labor market. In unreported results, a regression of 
$2010 \log$ comparative advantage in STEM jobs against the 1970 value yields a slope coefficient of 0.53 ( $t$-value 2.7) and an $R^{2}$ of 0.42 . Whatever factors drive immigrants from particular origin countries and regions to specialize in particular occupations in the United States, they appear to change slowly across decades.

A second pattern evident in figure 1.7, panel A, is positive drift. Most countries lie above the 45-degree line, indicating that log comparative advantage in STEM relative to US native-born workers was stronger in 2010 than in 1990. As seen in figure 1.5, this positive drift is a new phenomenon. In unreported results, we plot comparative advantage in STEM for 2010 against 1970 and find a more even distribution of countries above and below the 45-degree line, indicating that over a full forty-year time span, countries are mixed in terms of whether their comparative advantage in STEM is strengthening or weakening relative to the United States. A third pattern evident in figure 1.7, panel A, relates to the exceptionalism of India, a country frequently singled out for having benefited from access to $\mathrm{H}-1 \mathrm{~B}$ visas. Although India is the top country in terms of comparative advantage in STEM occupations for 2010, other countries also display high levels of specialization in the field. Immigrants from France, China, and Hong Kong also have relative log odds of working in STEM in 2010 of over two (as compared to 2.86 for India).

Does persistence in immigrant comparative advantage apply as strongly for women as it does for men? In figure 1.7, panel B, we plot log comparative advantage in STEM for female immigrants. Patterns are very similar to those for men, displaying both strong persistence and positive drift over time. As suggested by figures 1.5 and 1.6, male and female immigrants from the same origin country tend to have a comparative advantage in similar occupations. In 2010, the correlation in log comparative advantage for male and female immigrants is 0.92 in the STEM field. This commonality is not unique to STEM. For other occupations in that year, the correlation in log comparative advantage for males and females is 0.86 in management and finance, 0.71 in health-related occupations, 0.67 in education and law, and 0.59 in administrative support. This similarity in occupational specialization by male and female immigrants from the same origin country is present in earlier years, as well. ${ }^{12}$

Next, we examine the persistence of comparative advantage for male college-educated immigrants in the other four occupations, shown in figure 1.8. Similar to STEM, these occupations display strong persistence over time in comparative advantage by immigrant origin country and a tendency for positive drift in comparative relative to US native-born workers, as indicated

12. In 1990, the correlation in log comparative advantage across origin countries for male and female immigrants is 0.82 in STEM, 0.73 in management and finance, 0.62 in health-related occupations, 0.66 in education and law, and 0.75 in administrative support. 


\section{Management \& Finance}

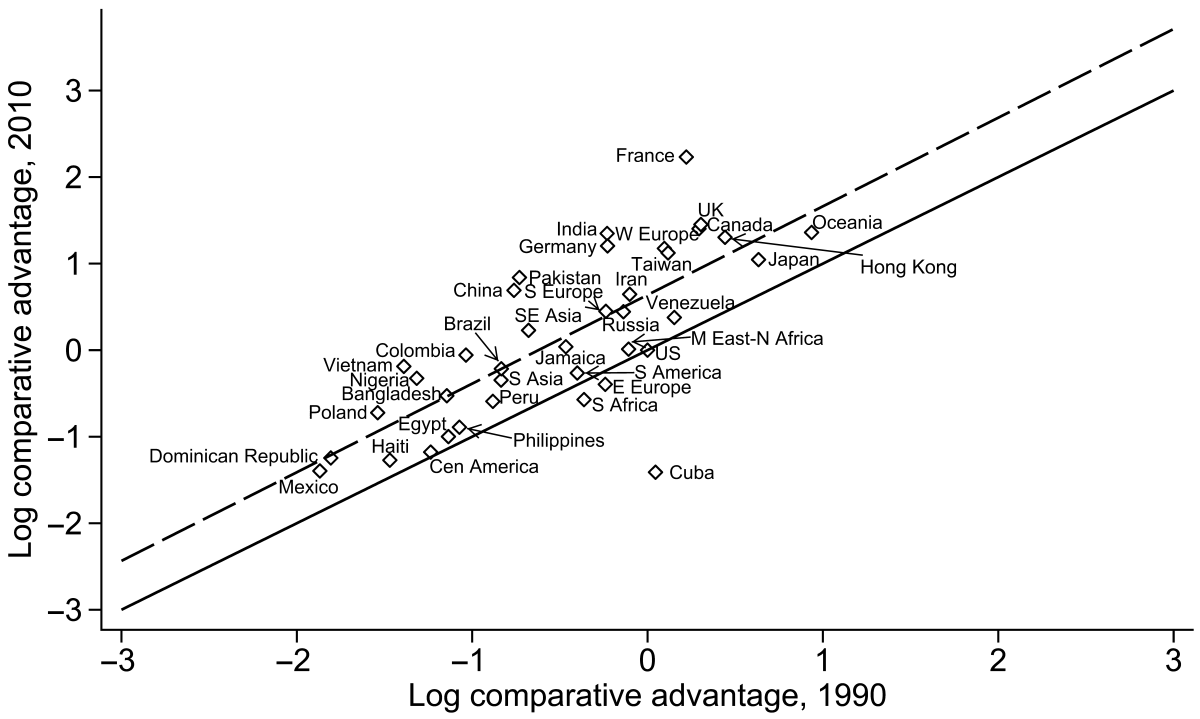

$\diamond \log \mathrm{CA} \longrightarrow 45$ degree line $-\longrightarrow$ Regression fit

Health Occupations

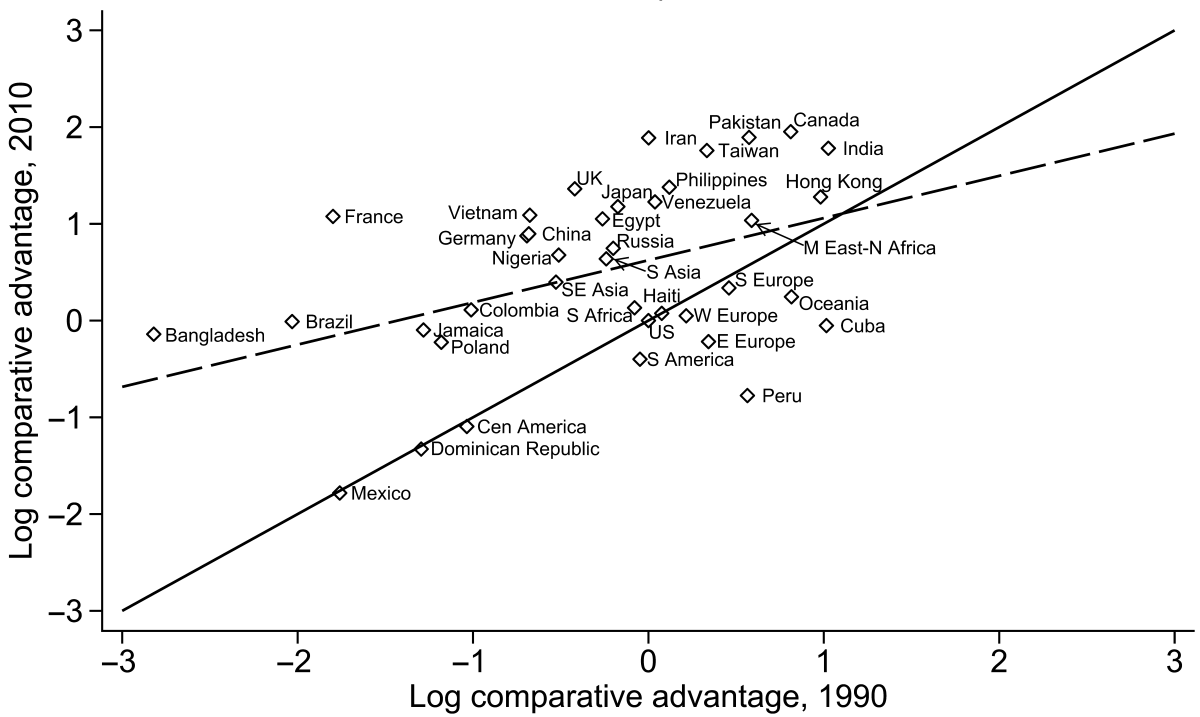

$\diamond \log \mathrm{CA}-45$ degree line -- Regression fit

Fig. 1.8 Log comparative advantage for male immigrants, 2010 versus 1990 


\section{Education, Law, the Arts}

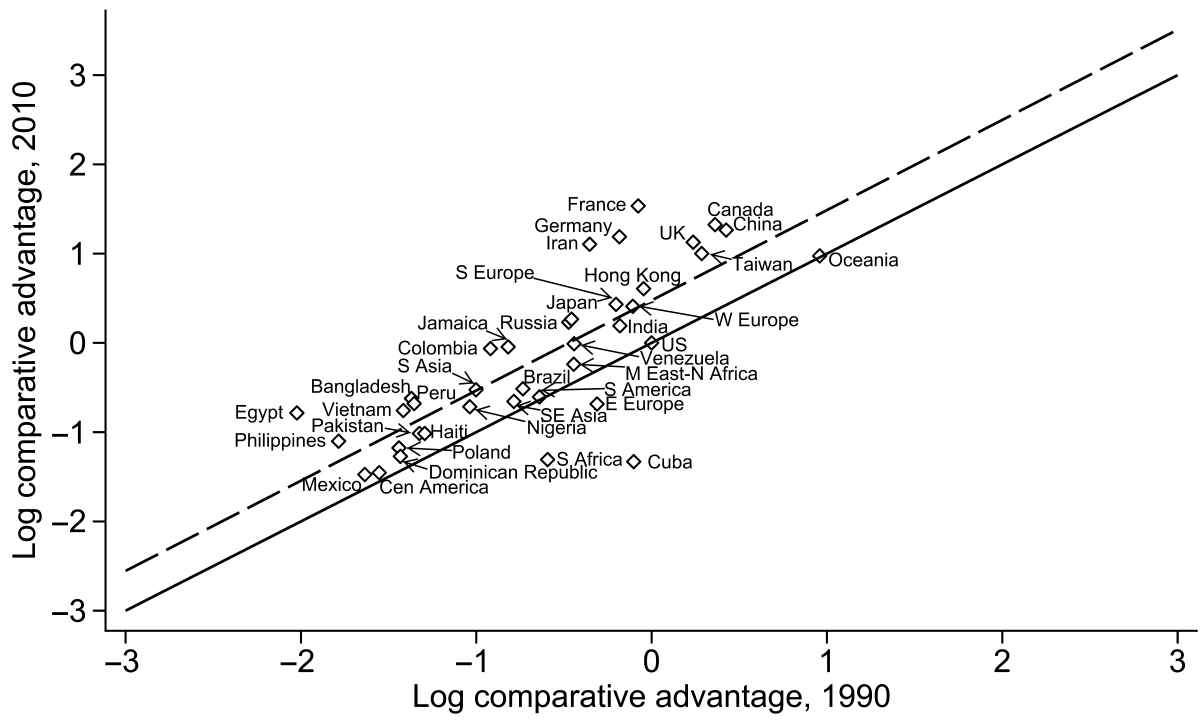

$\diamond \log C A-45$ degree line $-\longrightarrow$ Regression fit

Tech, Sales, Admin Support

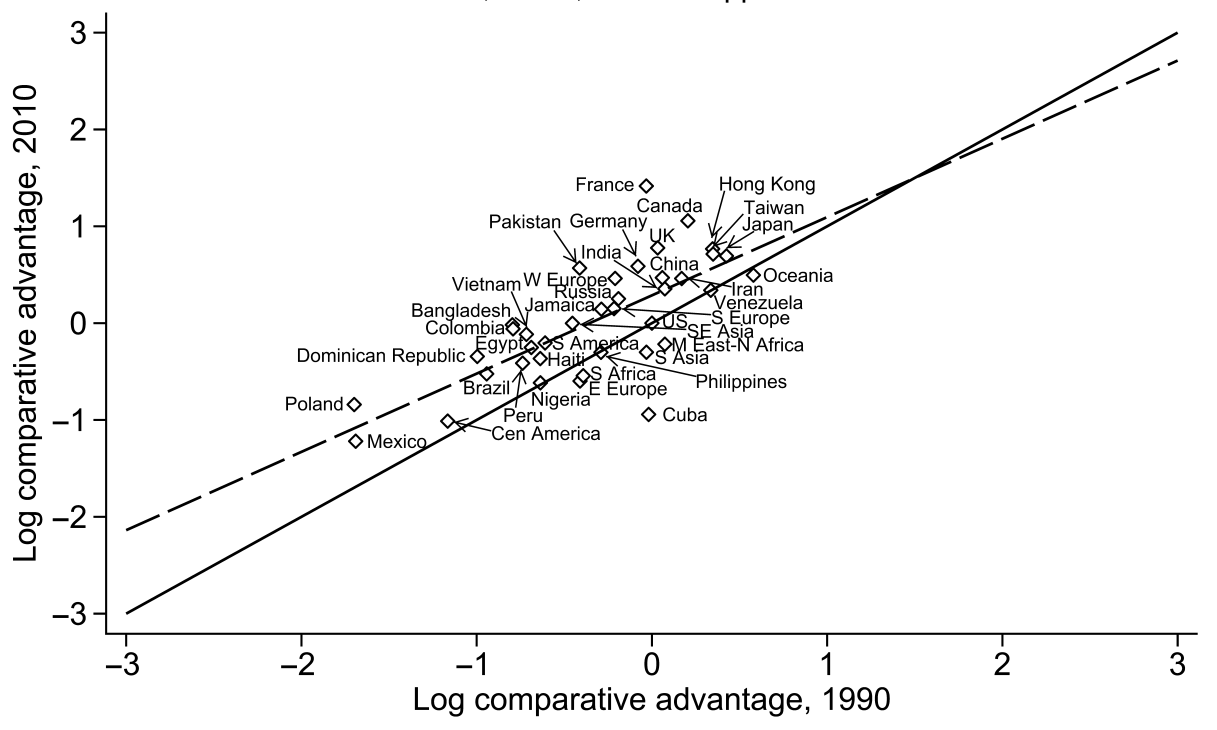

$\diamond \log \mathrm{CA} \longrightarrow 45$ degree line $-\longrightarrow$ Regression fit

Fig. 1.8 (cont.) 
by the mass of points lying above the 45-degree line. The slope coefficient ( $t$-value) for a regression of log comparative advantage in 2010 on 1990 values is 1.02 (6.8) in management and finance, 0.43 (2.9) in health-related occupations, 1.01 (7.7) in education and law, and 0.81 (6.4) in administrative support. Persistence in comparative advantage appears to be weakest in health-related occupations. In unreported results, we find patterns in comparative advantage in these occupations for women that are similar to those for men, though for women, persistence in comparative advantage appears to be somewhat weaker. ${ }^{13}$

What explains the persistence in occupational comparative advantage for immigrants across time? One possibility is long-standing differences between countries in the quality of educational institutions or occupational training. Russia's preeminence in mathematics dates back to the eighteenth century, which may have helped create a long-lived tendency for Russian migrants abroad to pursue occupations that are intensive in the use of quantitative reasoning. If differences in educational quality are a root cause of comparative advantage, we should observe differences in occupational choice between immigrants from Russia who arrive in the United States as adults, thus having completed their education in the origin country, and immigrants who arrive in the United States as children, who complete their education in US schools. In figure 1.9, we plot comparative advantage for two groups of male immigrants twenty-one to thirty-seven years old: one group that arrived in the United States at age eighteen or older, whose comparative advantage is given by values on the vertical axis, and a second group that arrived in the United States before age eighteen, whose comparative advantage is given by values on the horizontal axis. For all occupations, the slope coefficient is near one. Occupational comparative advantage for immigrants who arrive as children is nearly identical to that for immigrants who arrive as adults. We find similarly strong positive correlations in comparative advantage between immigrants who arrive as adults and immigrants who arrive as young children (age twelve or younger). These results suggest that the origin of immigrant comparative advantage by occupation is not the country in which one completes tertiary education or even the country in which one completes secondary education. The transmission of occupational skills to a nation's workers (or at least to the workers who migrate abroad) appears to operate through mechanisms other than direct learning in school.

A second explanation for persistence in immigrant occupational comparative advantage is the presence of job networks that are specific to

13. For the sample of female workers, the slope coefficient ( $t$-value) for a regression of $\log$ comparative advantage in 2010 on the 1990 value is .62 (4.3) in STEM occupations, 0.48 (3.24) in management and finance, 0.60 (4.22) in health-related occupations, 0.49 (4.42) in education and law, and $0.26(1.84)$ in administrative support. 


\section{STEM Occupations}

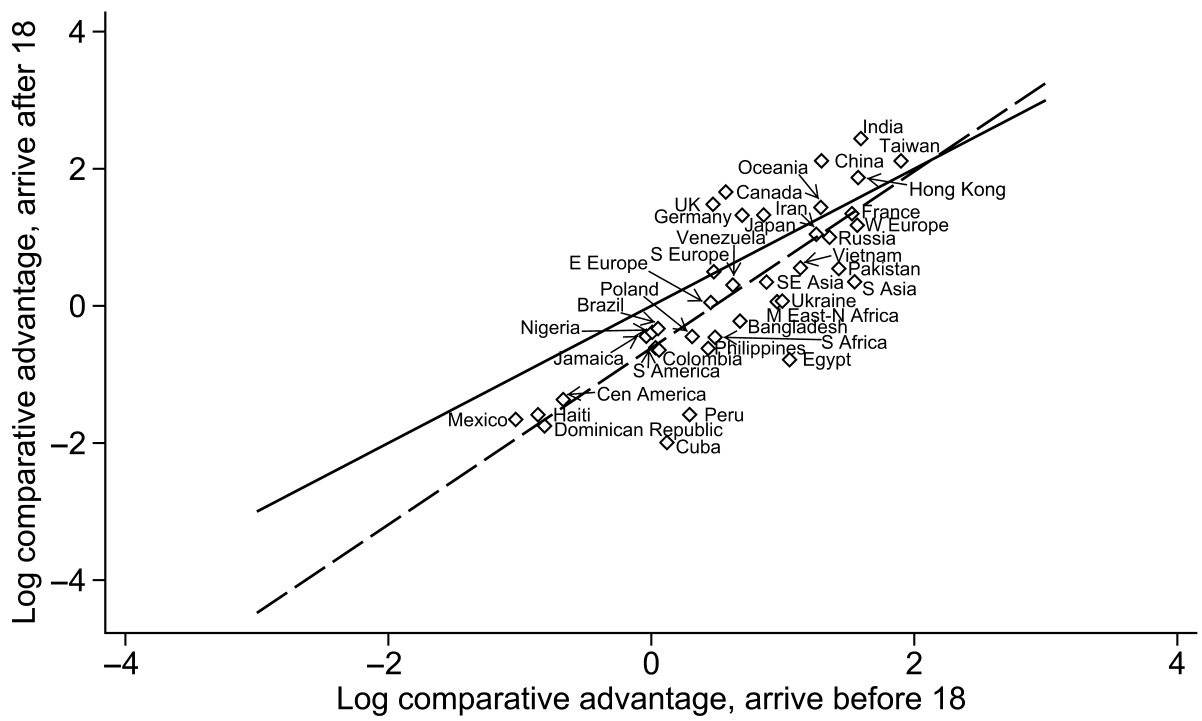

$\diamond \log \mathrm{CA}$ 45 degree line $-\longrightarrow$ Regression fit

\section{Management \& Finance}

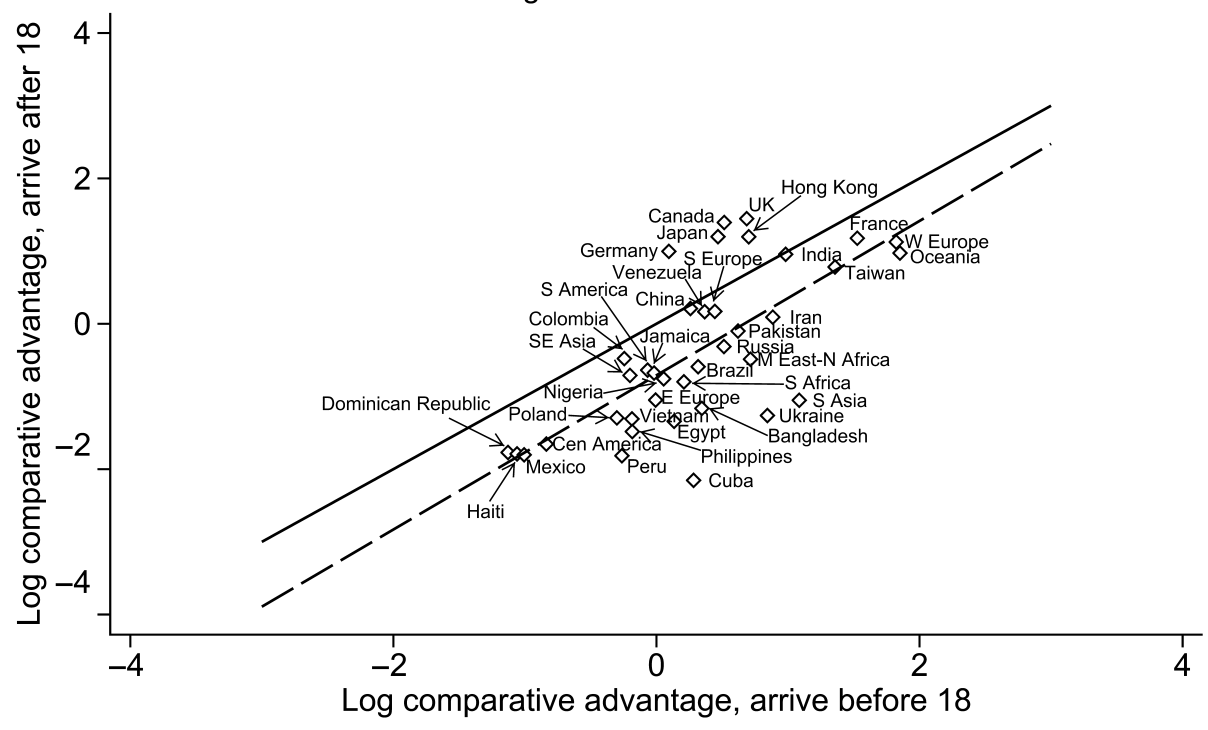

$\diamond \log C A-45$ degree line -- Regression fit

Fig. 1.9 Log comparative advantage for male immigrants in 2010-2012, US arrivals at age birth to seventeen versus US arrivals at age eighteen or older 
Health Occupations

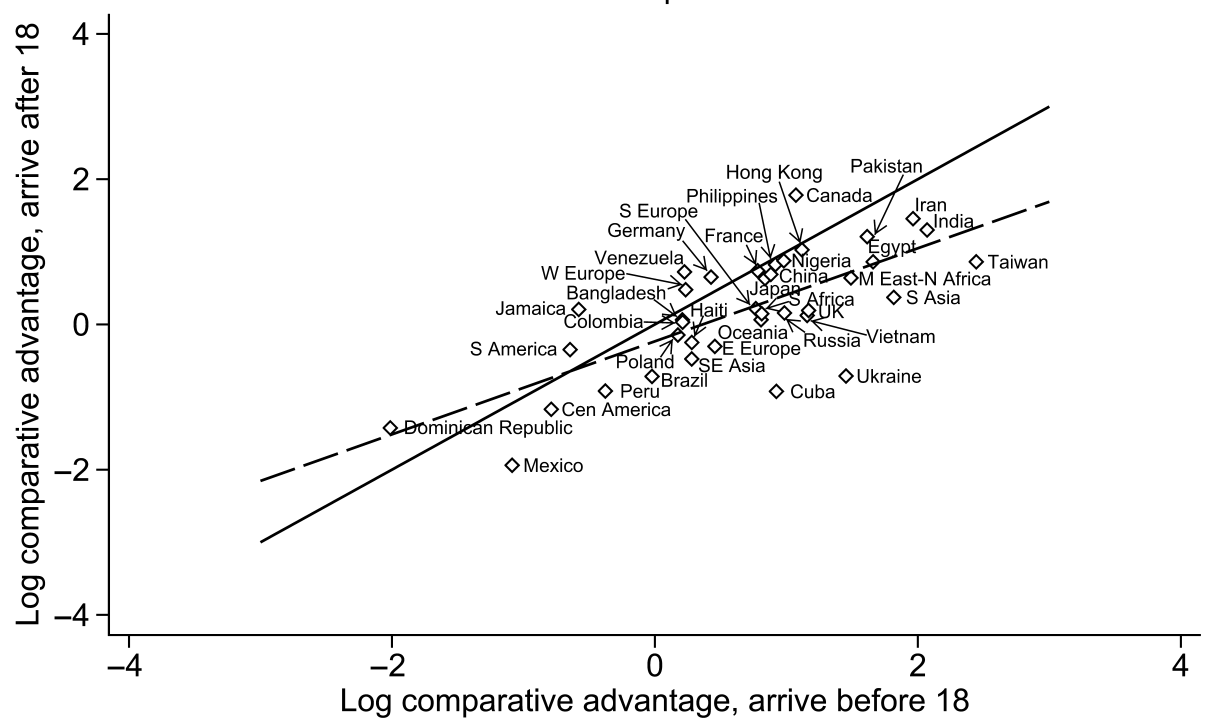

$\diamond \log C A-45$ degree line $\_-$regression fit

Education, Law, the Arts

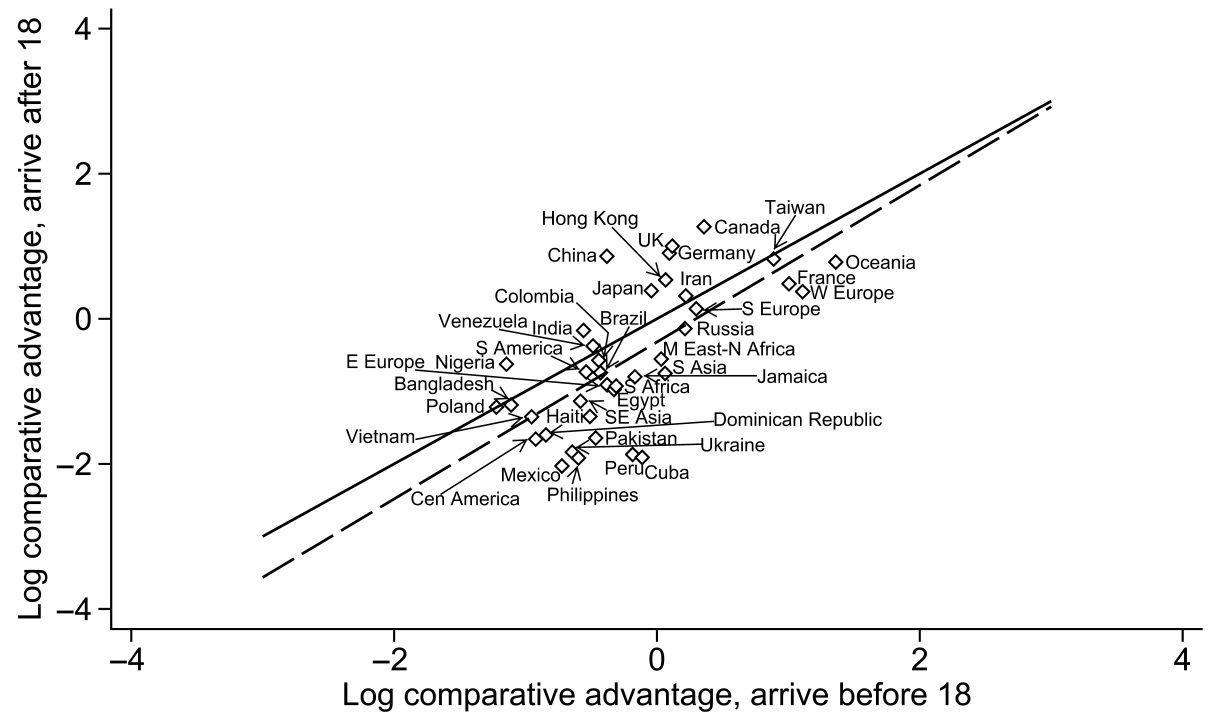

$\diamond \log C A-45$ degree line $-\longrightarrow$ regression fit

Fig. 1.9 (cont.) 


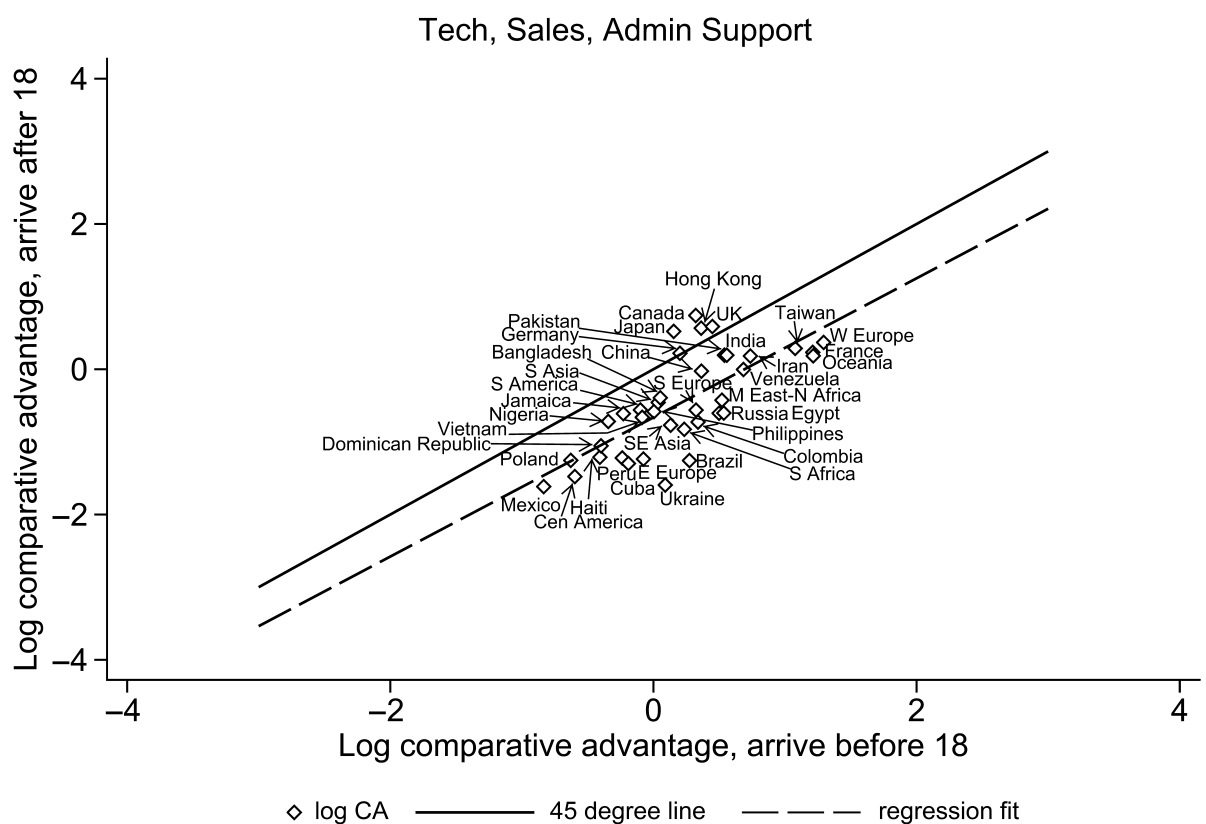

Fig. 1.9 (cont.)

individuals from the same origin country. A preponderance of immigrants from India working in the software industry, for instance, may lower search costs in the sector for recently arrived Indian workers, making them relatively likely to take up software jobs (Card 2001). As in the Ellison and Glaeser (1997) analysis of US industry agglomeration, occupational specialization of immigrants due to comparative advantage (arising, for example, from origin-country educational institutions) is observationally equivalent to occupational specialization due to origin-country-specific external economies (resulting, for example, from knowledge spillovers between immigrant workers with common ancestry). We acknowledge that externalities in occupational choice across workers from the same origin country may exist, but we lack empirical leverage to distinguish this source of occupational specialization from traditional comparative advantage.

A third explanation for occupational specialization patterns by origin country is family reunification provisions of US immigration policy. By favoring new immigrants who have kinship connections to existing US residents, US immigration policy may select immigrants who are disproportionately likely to learn job and other skills from earlier arrivals from the same origin country. The occupational skills picked up by immigrant arrivals from China in the 1980s may then transmit to immigrant arrivals from China in 
the 1990s and early in the twenty-first century, due in part to the earlier arrivals consisting of many of their relatives.

\subsubsection{Ancestry Analysis}

A further way to identify the types of mechanisms that may transmit occupational skills across individuals with a given nationality is to compare job choice by immigrants from a particular origin country with native-born workers who have ancestral ties to that origin nation. If transmission mechanisms (e.g., job-search networks) operate on the basis of country of birth, then we would expect to see immigrants from a particular origin country (e.g., India) choosing common occupations in the United States, regardless of whether they arrived in the country as children or as adults. But there is no reason occupational choice among Indian immigrants, say, will overlap with that for native-born US residents of Indian heritage unless these jobsearch networks are spread broadly throughout the Indian community in the United States.

Our final exercise is to examine comparative advantage for three groups of workers: immigrants from a given origin country who arrive in the United States at or after age eighteen, immigrants from a given origin country who arrive in the United States before age eighteen, and individuals born in the United States (or abroad to US citizens) who claim ancestry from a given origin country. We define ancestry according to the first country of ancestry an individual selects in census or ACS surveys. It is important to note that these surveys do not distinguish ancestry according to the number of generations from which an individual is removed from immigration. Sharing a common ancestry thus may combine those whose parents were born abroad with those who families have resided in the United States for many generations. We again define origin countries (and now ancestral countries) using the forty country/region groups defined in the previous section. The sample is college-educated males between twenty-one to forty-four years old. (See table 1.1.)

Figure 1.10 plots log comparative advantage in STEM occupations for immigrants who arrived in the United States as adults (y-axis of the top panel) and for immigrants who arrived as children (y-axis of the bottom panel) against that for US native-born individuals with the same ancestry (x-axis). In both panels, there is a strong positive correlation between immigrant comparative advantage in STEM and comparative advantage in STEM for US native-born individuals with common ancestry. In the left panel (immigrants who arrived as adults), the slope coefficient is 0.92 ( $t$-value 3.43) with an $R^{2}$ of 0.25 , while in the right panel (immigrants who arrived as children) the slope coefficient is 0.68 ( $t$-value 4.23) with an $R^{2}$ of 0.32. The persistence in comparative advantage in STEM thus applies across generations: current generations of immigrants show a tendency to 
Table 1.1

Dispersion of log comparative advantages by occupations and groups

\begin{tabular}{llc}
\hline Group & \multicolumn{1}{c}{ Occupation } & Standard deviation \\
\hline Immigrants arrival after 18 & STEM & 1.34 \\
Immigrants arrival before 17 & STEM & 0.85 \\
Native, same ancestry & STEM & 0.68 \\
Immigrants arrival after 18 & Management \& finance & 1.15 \\
Immigrants arrival before 17 & Management \& finance & 0.75 \\
Native, same ancestry & Management \& finance & 0.59 \\
Immigrants arrival after 18 & Health occupations & 1.15 \\
Immigrants arrival before 17 & Health occupations & 1.09 \\
Native, same ancestry & Health occupations & 0.97 \\
Immigrants arrival after 18 & Education, law, the arts & 1.13 \\
Immigrants arrival before 17 & Education, law, the arts & 0.81 \\
Native, same ancestry & Education, law, the arts & 0.55 \\
Immigrants arrival after 18 & Tech, sales, admin support & 0.76 \\
Immigrants arrival before 17 & Tech, sales, admin support & 0.63 \\
Native, same ancestry & Tech, sales, admin support & 0.48 \\
\hline
\end{tabular}

specialize in STEM jobs that is strongly related to the tendency of current descendants of earlier immigrants.

Next, in figure 1.11 we display the analogous comparative advantage plots for immigrants and common-ancestry, native-born workers in other occupations. These plots also reveal positive correlations in comparative advantages for immigrants and common-ancestry natives, but these correlations are weaker than for STEM. Slope coefficients in the left panels (for immigrants who arrived in the United States as adults) are 0.53 ( $t$-value 1.80 ) in management and finance; 0.60 ( $t$-value 3.76 ) in health occupations; 0.41 ( $t$-value 1.28) in education, law, and the arts; and 0.31 ( $t$-value 1.31) in technical, sales, and administrative support. Corresponding slope coefficients for immigrants who arrived as children are slightly smaller in all cases.

One pattern that is evident in figures 1.10 and 1.11 is that dispersion in comparative advantage tends to be higher among immigrant workers than among common-ancestry, native-born workers. In table 1.1, we summarize dispersion in comparative advantage across origin countries for each nativity group (immigrants who arrived as adults, immigrants who arrived as children, and common-ancestry, native-born workers) in each of the five occupation groups. For each occupation, dispersion in comparative advantage decreases with time in the United States: it is highest among immigrants who arrived in the United States as adults, second highest among immigrants who arrived in the United States as children, and lowest among commonancestry, native-born individuals. Accumulated time in the United States thus seems to be associated with attenuation in the impact of origin-country factors that create occupational comparative advantage. 


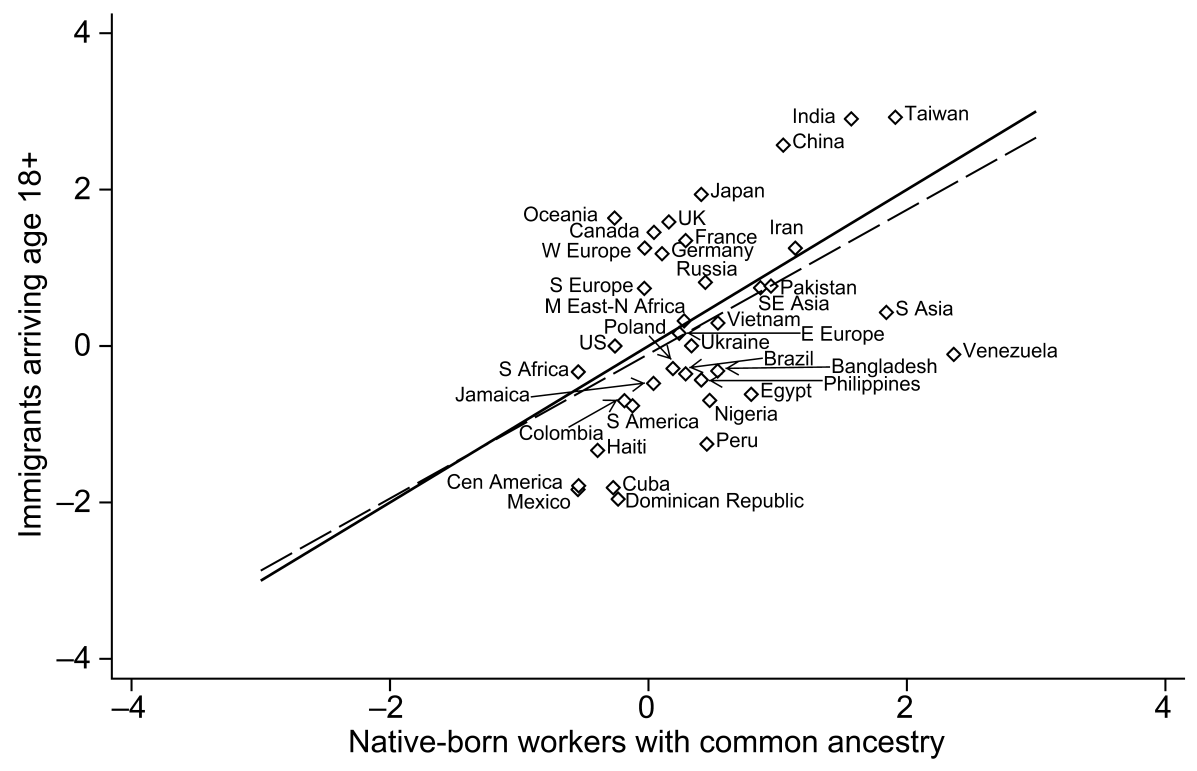

$\diamond \log C A-45$ degree line -- Regression fit

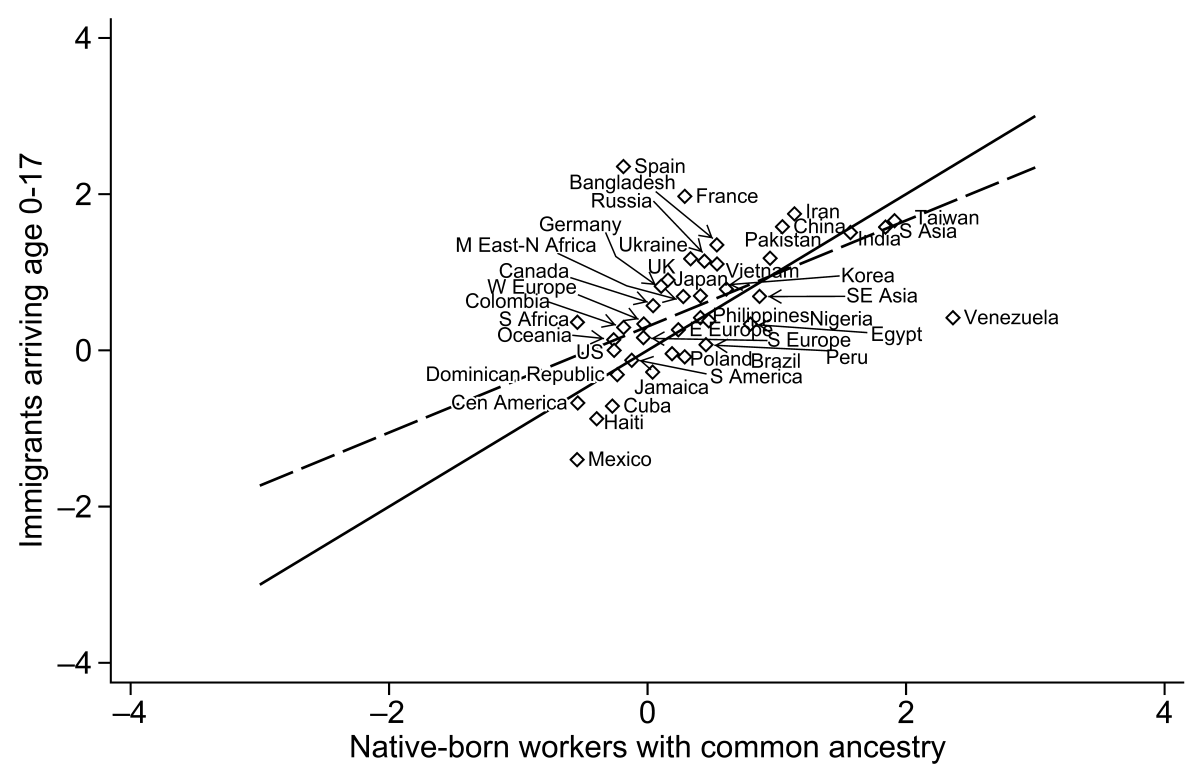

$\diamond \log C A-45$ degree line --- Regression fit

Fig. 1.10 Log comparative advantage in STEM for immigrants versus native-born workers with common ancestry, males 2010-2012 


\section{Management \& Finance}
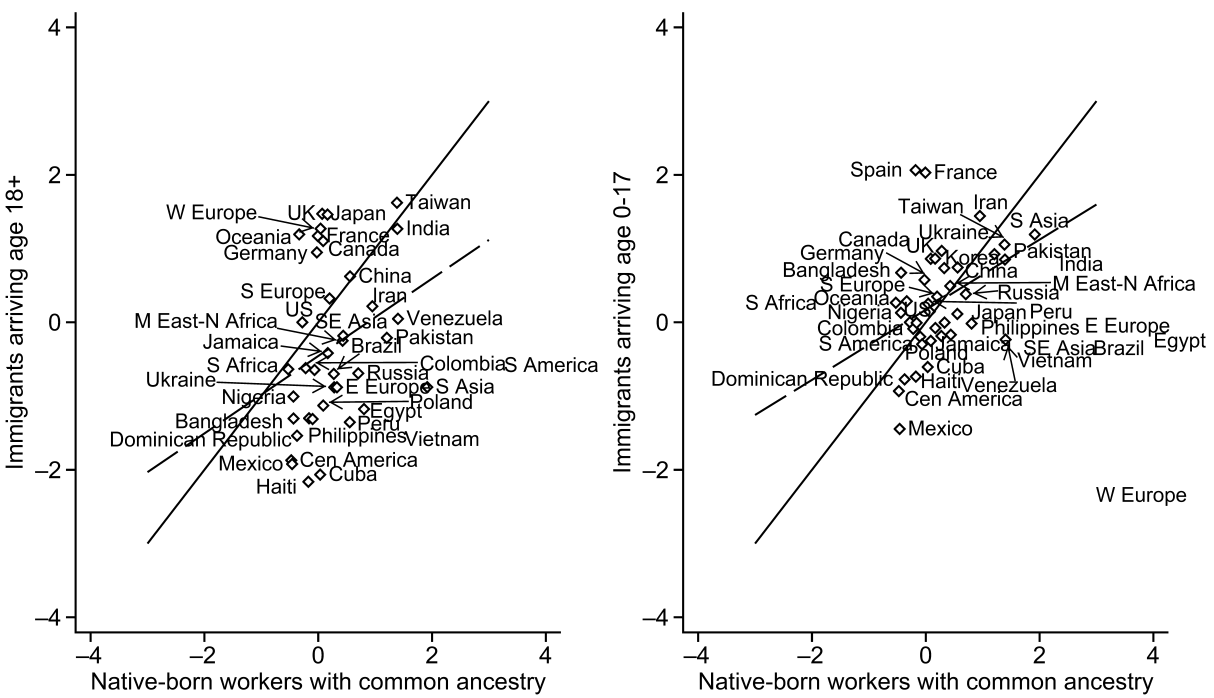

$\diamond \log C A$

45 degree line

Regression fit

\section{Health Occupations}
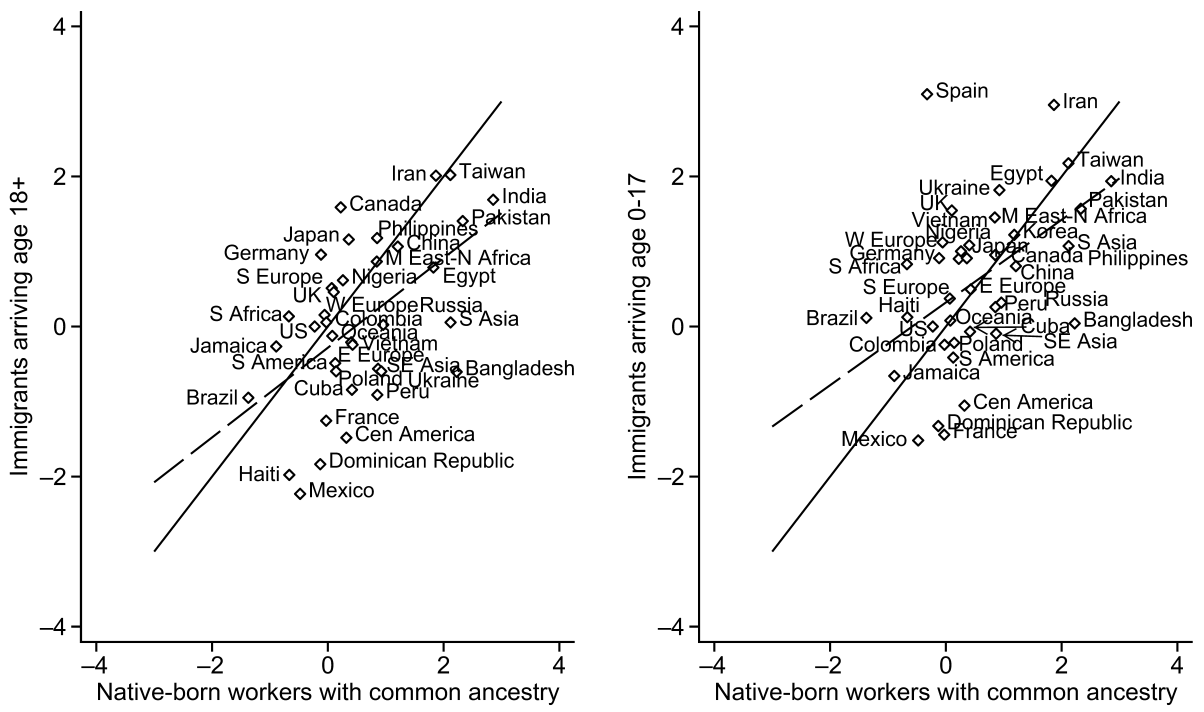

$\diamond \log C A$

45 degree line

Regression fit

Fig. 1.11 Log comparative advantage in other occupations for immigrants versus native-born workers with common ancestry, males 2010-2012 


\section{Education, Law, the Arts}
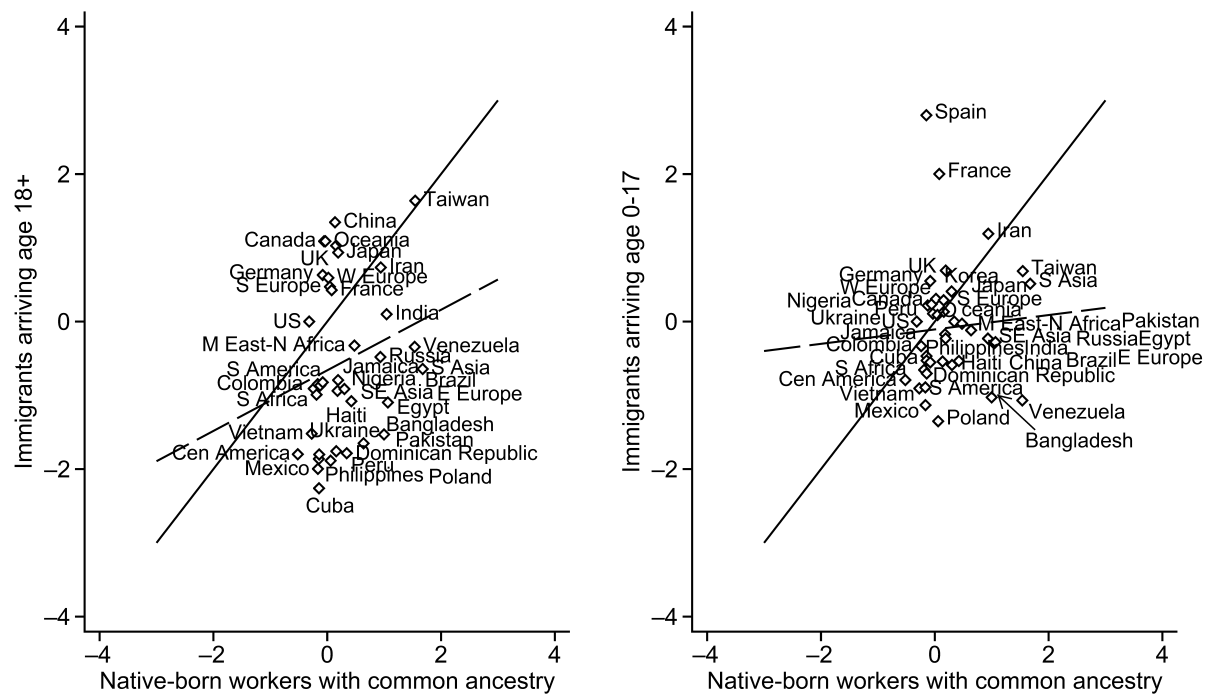

$\diamond \log \mathrm{CA} \longrightarrow 45$ degree line $-\longrightarrow$ Regression fit

Tech, Sales, Admin Support
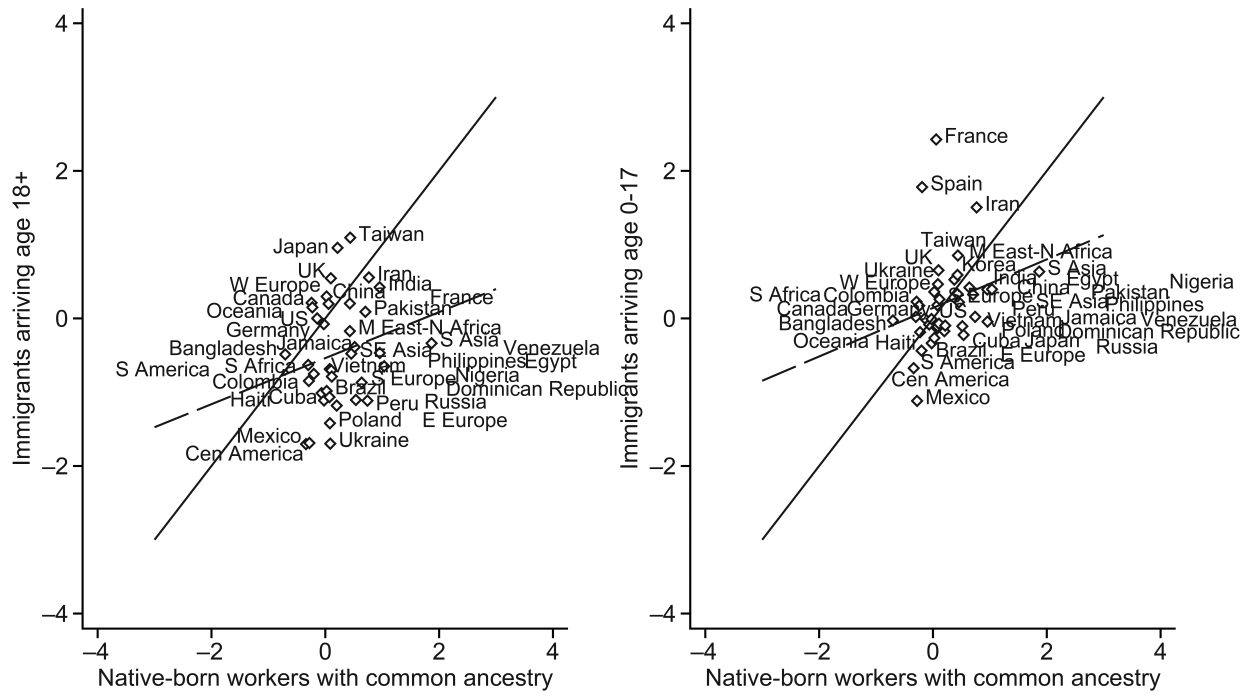

$\diamond \log C A-45$ degree line $--\longrightarrow$ Regression fit

Fig. 1.11 (cont.) 


\subsection{Discussion}

The United States has built its strength in high technology in part through its businesses having access to exceptional talent in science, engineering, and mathematics. Although US universities continue to dominate STEM disciplines globally, it is individuals born abroad who increasingly make up the US STEM labor force. The success of Amazon, Facebook, Google, Microsoft, and other technology standouts seems to hinge, at least in part, on the ability of the US economy to import talent from abroad. US continued success in STEM fields thus may depend on which immigrants the country chooses to admit.

We document strong differences across origin countries in occupational specialization patterns by foreign-born workers in the US economy. Immigrants from China, India, and some other countries in Asia are much more likely to specialize in STEM occupations than are native-born workers or immigrants from other origin regions. These specialization patterns are persistent across time, common to males and females from the same origin countries, common to immigrants from an origin country regardless of their age of arrival in the United States, and even common to immigrants and native-born workers who share a common ancestry. Persistence in occupational specialization patterns across age cohorts, arrival cohorts, and nativity cohorts suggests that factors other than the country in which one completes secondary or tertiary schooling play a role in occupational sorting. These additional factors may include job-search networks that are specific to ethnic groups and cultural norms that vary across origin countries and ethnicities in the prestige assigned to particular occupations.

\section{References}

Borjas, George, and Kirk Doran. 2012. "The Collapse of the Soviet Union and the Productivity of American Mathematicians." Quarterly Journal of Economics 127 (3): 1143-203.

Bound, John, Murat Demirci, Gaurav Khanna, and Sarah Turner. 2015. "Finishing Degrees and Finding Jobs: US Higher Education and the Flow of Foreign IT Workers." In Innovation Policy and the Economy, vol. 15, edited by William R. Kerr, Josh Lerner, and Scott Stern. Chicago: University of Chicago Press.

Burstein, A., G. H. Hanson, L. Tian, and J. Vogel. 2017. "Tradability and the Labor Market Impact of Immigration: Theory and Evidence for the US" NBER Working Paper no. 23330, Cambridge, MA.

Burstein, A., E. Morales, and J. Vogel. 2015. "Accounting for Changes in BetweenGroup Inequality.” NBER Working Paper no. 20855, Cambridge, MA.

Card, David. 2001. "Immigrant Inflows, Native Outflows, and the Local Labor Market Impacts of Higher Immigration." Journal of Labor Economics 19 (1): 22-64.

Clemens, Michael. 2010. "The Roots of Global Wage Gaps: Evidence from Random- 
ized Processing of US Visas." Center for Global Development Working Paper no. 212. https://www.cgdev.org/publication/roots-global-wage-gaps-evidence -randomized-processing-us-visas-working-paper-212.

Eaton, Jonathan, and Samuel Kortum. 2002. "Technology, Geography, and Trade." Econometrica 70 (5): 1741-79.

Ellison, Glenn, and Edward L. Glaeser. 1997. "Geographic Concentration in US Manufacturing Industries: A Dartboard Approach.” Journal of Political Economy 105 (5): 889-927.

Freeman, Richard. 2005. "Does Globalization of the Scientific/Engineering Workforce Threaten US Economic Leadership?” NBER Working Paper no. 11457, Cambridge, MA.

General Accounting Office. 2011. "H-1B Visa Program: Reforms Are Needed to Minimize the Risks and Costs of Current Program." GAO Report no. 11-26, Washington, DC, General Accounting Office. http://www.gao.gov/products /GAO-11-26.

Goldin, Claudia, and Lawrence F. Katz. 2008. The Race between Education and Technology. Cambridge, MA: Harvard University Press.

Grogger, Jeffrey, and Gordon H. Hanson. 2015. "Attracting Talent: Location Choices of Foreign-Born PhDs in the United States." Journal of Labor Economics 33 (S1): S5-38.

Hanushek, Eric A., and Dennis D. Kimko. 2000. "Schooling, Labor-Force Quality, and the Growth of Nations." American Economic Review 90 (5): 1184-208.

Hsieh, C.-T., E. Hurst, C. I. Jones, and P. J. Klenow. 2013. "The Allocation of Talent and US Economic Growth." NBER Working Paper no. 18693, Cambridge, MA.

Hunt, Jennifer. 2011. "Which Immigrants Are Most Innovative and Entrepreneurial? Distinctions by Entry Visa.” Journal of Labor Economics 29 (3): 417-57.

Hunt, Jennifer, and Marjolaine Gauthier-Loiselle. 2010. "How Much Does Immigration Boost Innovation?" American Economic Journal: Macroeconomics 2 (2): 31-56.

Institute of International Education. 2015. "Top 25 Places of Origin of International Students, 2013/14-2014/15.” Open Doors Report on International Educational Exchange. http://www.iie.org/opendoors.

Jasso, Guillermina, Douglas S. Massey, Mark R. Rosenzweig, and James P. Smith. 2000. "Assortative Mating among Married New Legal Immigrants to the United States: Evidence from the New Immigrant Survey Pilot." International Migration Review 34 (2): 443-59.

Jones, Charles I. 2002. "Sources of US Economic Growth in a World of Ideas." American Economic Review 92 (1): 220-39.

Kato, Takao, and Chad Sparber. 2013. "Quotas and Quality: The Effect of H-1B Visa Restrictions on the Pool of Prospective Undergraduate Students from Abroad." Review of Economics and Statistics 95 (1): 109-26.

Katz, L. F., and David H. Autor. 1999. "Changes in the Wage Structure and Earnings Inequality." Handbook of Labor Economics 3:1463-555.

Kerr, William R., and William F. Lincoln. 2010. "The Supply Side of Innovation: H-1B Visa Reforms and US Ethnic Invention." Journal of Labor Economics 28 (3): 473-508.

Lagakos, David, and Michael E. Waugh. 2013. "Selection, Agriculture, and CrossCountry Productivity Differences.” American Economic Review 103 (2): 948-80.

Lowell, B. Lindsay. 2000. "H-1B Temporary Workers: Estimating the Population." CCIS Working Paper no. 12, Center for Comparative Immigration Studies, University of California, San Diego. http://escholarship.org/uc/item/4ms039dc.

Ngai, Mae M. 1999. "The Architecture of Race in American Immigration Law: A 
Reexamination of the Immigration Act of 1924." Journal of American History 86 (1): 67-92.

Peri, Giovanni. 2012. "The Effect of Immigration on Productivity: Evidence from US States." Review of Economics and Statistics 94 (1): 348-58.

Rosenzweig, Mark. 2006. "Global Wage Differences and International Student Flows." Brookings Trade Forum 2006:57-86.

2007. "Education and Migration: A Global Perspective." Working Paper, Yale University. http://siteresources.worldbank.org/EXTPREMNET/Resources /489960-1338997241035/Growth_Commission_Workshops_Equity_Rosenzweig _Presentation.pdf.

Roy, Andrew Donald. 1951. "Some Thoughts on the Distribution of Earnings." Oxford Economic Papers 3 (2): 135-46.

Ruggles, Steven, Matthew Sobek, Trent Alexander, Catherine A. Fitch, Ronald Goeken, Patricia Kelly Hall, Miriam King, and Chad Ronnander. 2010. Integrated Public Use Microdata Series: Version 3.0. Minneapolis: Minnesota Population Center.

Salzman, Hal, Daniel Kuehn, and B. Lindsay Lowell. 2013. "Guestworkers in the High-Skill US Labor Market.” EPI Briefing Paper no. 359, Economic Policy Institute.

Udansky, Margaret L., and Thomas J. Espenshade. 2000. "The H-1B Debate in Historical Perspective: The Evolution of US Policy toward Foreign-Born Workers." CCIS Working Paper no. 11, Center for Comparative Immigration Studies, University of California, San Diego. https://ccis.ucsd.edu/_files/wp11.pdf. 